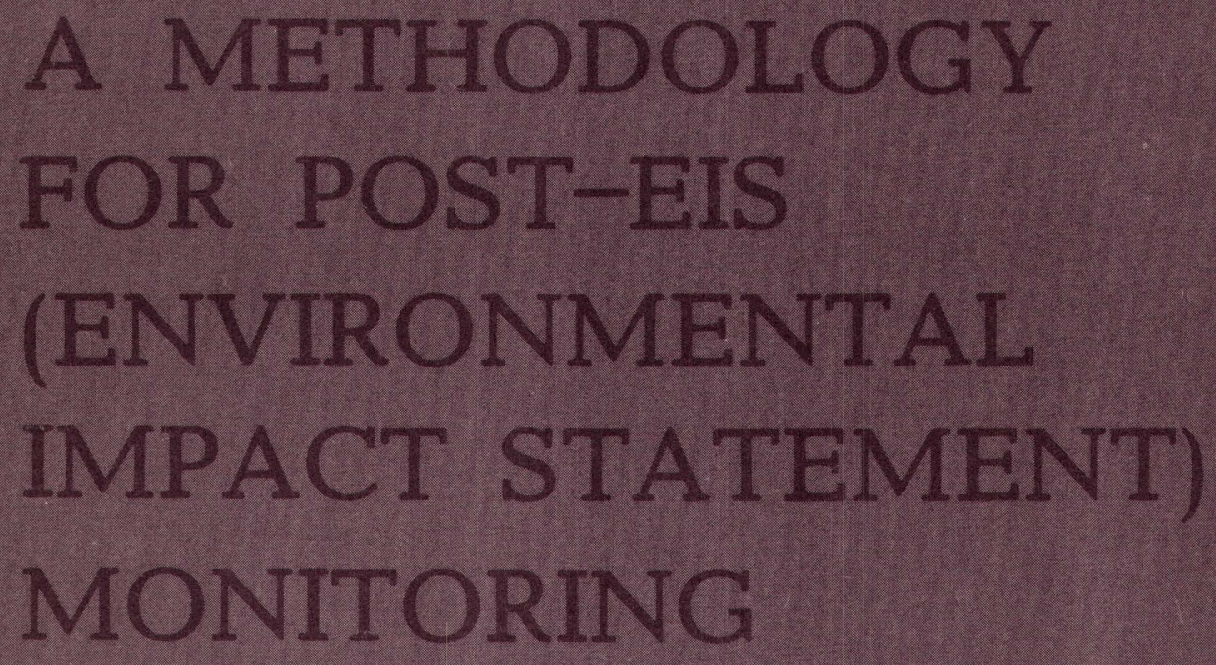

GEOLOGICAL SURVEY CIRCULAR 782
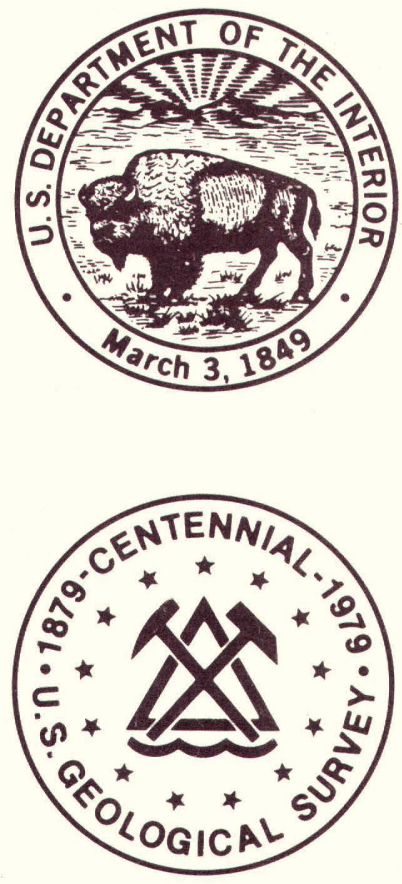
A METHODOLOGY FOR POST-EIS (ENVIRONMENTAL IMPACT STATEMENT) MONITORING

BY LINDA GRAVES MARCUS

GEOLOGY SURVEY CIRCULAR 782 


\section{United States Department of the Interior}

CECIL D. ANDRUS, Secretary

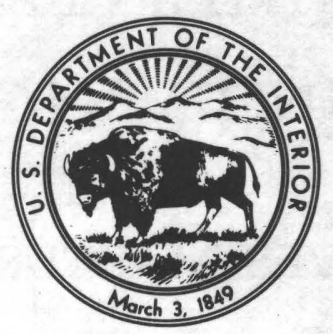

\section{Geological Survey}

H. William Menard, Director

\section{Library of Congress Cataloging in Publication Data}

Marcus, Linda Graves.

A methodology for post-EIS (environmental impact statement) monitoring.

(Geological Survey circular ; 782)

Bibliography: $p$.

1. Environmental impact statements. I. Title. II. Series: United States. Geological Survey. Circular ; 782.
QE75.C5
no. 782
[TD194.5]
$557.3^{\prime} 08 \mathrm{~s}$
[363.6]
78-19202 


\section{CONTENTS}

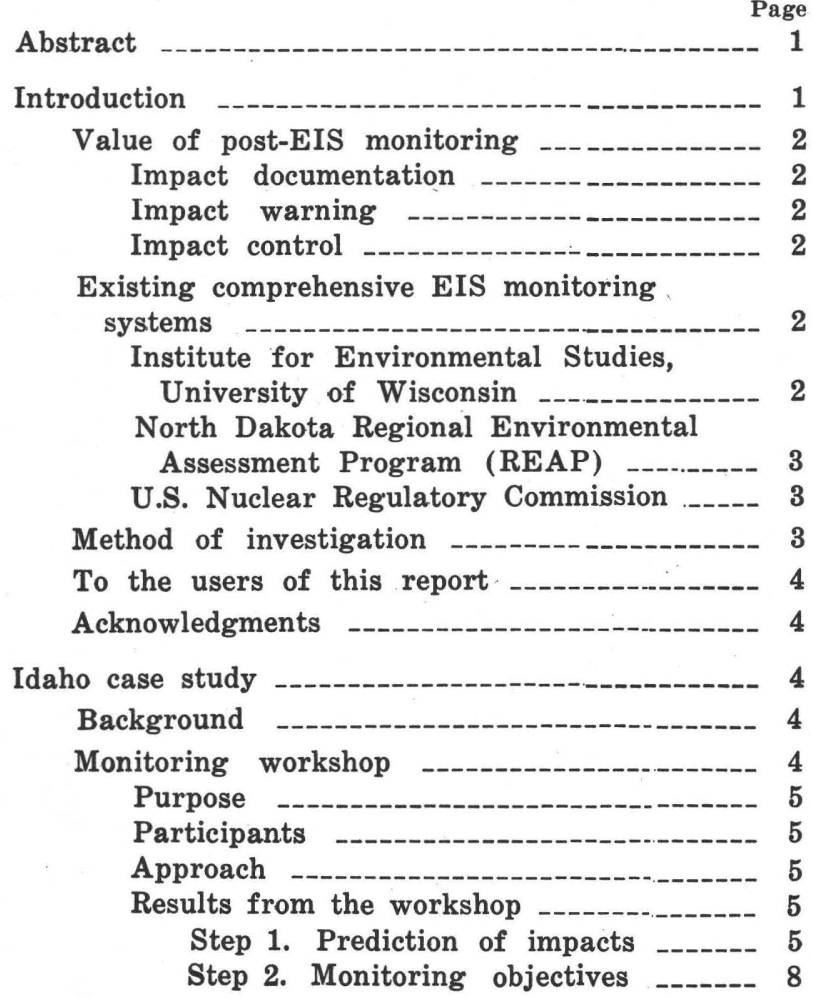

Step 3. Impacts selected for

Page

1

1

2

2

2

2

2

2

Monitorir

Introductodolo 26

Introduction -- 26

Focus of monitoring methodology ..-_-_-_-- 27

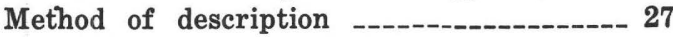

Phase I. Development of a monitoring system

Considerations for developing a

monitoring system -

Description of methodology, Phase I .--.-- 28

Phase II. Implementation and operation of

a monitoring system ----------------------- 28

Considerations for implementing and operating a monitoring system ..--.--- 28

Description of methodology, Phase II .----- 28

Summary and conclusions _-__-_-_ 39

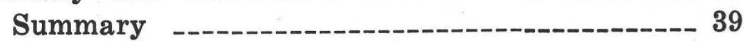

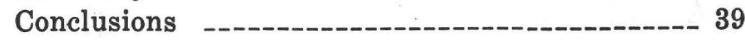

References cited -

\section{ILLUSTRATIONS}

[Plates are in pocket]

PLATE 1. Monitoring methodology flow chart: Phase I.

Development of a monitoring system.

2. Monitoring methodology flow chart: Phase II.

Implementation and operation of a monitoring system

Page

FIGURE 1. Activity/impact schedule ---

2. Assumed total production of phosphate in southeastern Idaho

through 1999 


\section{TABLES}

TABLE 1. Summary of impacts predicted in the EIS

Page

2. Example of a monitoring objectives worksheet

3. Example of compilation of data-needs worksheets

$-5$

4. Example of compilation of data-availability worksheets -

5. Activity/impact matrix : mining phosphate ore

6. Activity/impact matrix: processing phosphate ore

7. Monitoring data needs -

8. Explanation of flow chart of monitoring methodology:

Phase I. Development of a monitoring system

9. Explanation of flow chart of monitoring methodology:

Phase II. Implementation and operation of a monitoring system 


\title{
A Methodology for Post-ElS (Environmental Impact Statement) Monitoring
}

\author{
By Linda Graves Marcus
}

\begin{abstract}
A methodology for monitoring the impacts predicted in environmental impact statements (EIS's) was developed using the EIS on phosphate development in southeastern Idaho as a case study. A monitoring system based on this methodology: (1) coordinates a comprehensive, intergovernmental monitoring effort; (2) documents the major impacts that result, thereby improving the accuracy of impact predictions in future EIS's; (3) helps agencies control impacts by warning them when critical impact levels are reached and by providing feedback on the success of mitigating measures; and (4) limits monitoring data to the essential information that agencies need to carry out their regulatory and environmental protection responsibilities. The methodology is presented as flow charts accompanied by tables that describe the objectives, tasks, and products for each work element in the flow chart.
\end{abstract}

\section{INTRODUCTION}

This report describes a methodology for monitoring the impacts predicted in environmental impact statements (EIS's). Environmental impact statements describe the impacts anticipated from major Federal actions, ${ }^{1}$ but provision generally is not made as a part of the NEPA process to determine if the predicted impacts are accurately assessed or if unanticipated impacts occur. This report sets forth a strategy for monitoring impacts caused by major Federal actions as a means of verifying and improving the accuracy of EIS predictions and for controlling levels of impact.

\footnotetext{
${ }^{1}$ As defined by NEPA (National Environmental Policy Act of 1969), any Federal action that will significantly impact the human environment. Types of "actions" described in the act are described in the "Code of Federal Regulations" (Office of the Federal Register, 1977).
}

Monitoring is not presently provided for or explicitly required under NEPA. However, section 101.6 of the act states that "it is the continuing responsibility of the Federal Government to use all practical means $* * *$ to coordinate Federal plans, functions, programs, and resources to the end that the nation may *** Assure for all Americans safe, healthful, productive, and esthetically and culturally pleasing surroundings." Further, a memorandum from the Assistant Solicitor-Minerals to the Director of the U.S. Geological Survey (July 10, 1975) indicated that several statutes (including NEPA), regulations, and executive orders implicitly require environmental monitoring. However, a clear directive as to what conditions or actions require environmental monitoring does not exist.

In 1976 the Council on Environmental Quality (CEQ), the agency responsible for carrying out NEPA and setting guidelines for EIS preparation, sponsored a "sub-task force on post-EIS ecological impact assessment and monitoring." The task force recommended the following for inclusion in the CEQ environmental impact statement guidelines:

Agencies which produce Environmental Impact Statements must establish a continuing program of post-EIS follow-up of ecological predictions for projects or programs within major EIS categories. Such follow-up, or monitoring, will both insure that appropriate and practical adjustments will be made during the life of the project and that insight gained can be applied to improvement of future ecological predictions. (Written commun., Kevin T. Mullen, December 1976.) 
Kevin T. Mullen, then Executive Director of the Federal Committee on Ecology, CEQ, indicated a strong likelihood of this recommendation being implemented as a CEQ guideline (oral commun., December 1976).

Post-EIS monitoring has not been implemented for several reasons:

1. NEPA does not specifically require it, and CEQ has not yet promulgated guidelines requiring monitoring to fulfill the intent of NEPA.

2. Agencies are concerned that monitoring would require the diversion of funds and personnel from existing agency programs.

3. Institutional arrangements do not presently exist for implementing interagency, intergovernmental monitoring which includes both collection of monitoring data and control of impacts.

\section{VALUE OF POST-EIS MONITORING}

\section{IMPACT DOCUMENTATION}

In many cases, Federal agencies preparing environmental impact statements need documentation of the impacts that result from a proposed Federal action to predict more accurately the impacts associated with similar Federal actions. For example, increased mineral resource development has resulted in the preparation by the U.S. Geological Survey of a number of EIS's for mining and reclamation plans. EIS's prepared on future mineral resource development actions in the same geographic areas would greatly benefit from documentation of the impacts that actually resulted from previous actions. Lease stipulations to reduce impacts would also benefit from documentation of impact.

\section{IMPACT WARNING}

A monitoring system could warn agencies of unanticipated adverse impacts or sudden changes in impact trends and could provide immediate warning whenever an impact indicator approaches a critical level. Some possible approaches for defining critical levels could be defined in terms of carrying capacity, threshold levels, or regulation and enforcement standards.

\section{IMPAGT GONTROL}

Agencies at all levels of government collectively have substantial potential to control the timing, location, and level of impacts. These controls basically fall under the following categories: (1) decisionmaking-for example, determination of what limits will be placed on the activities causing the impact, establishment of new fiscal policies, implementation of potential mitigating measures, and management of environmental resources; (2) planning-for example, planning development of community infrastructures, planning the location and type of land-use change, and planning for multipleuse development of res iurces; and (3) regulation and enforcement-for example, enforcement of the terms of sining and reclamation plans, enforcement of air- and water-quality standards, and development of impact reduction or prevention regulations.

Agencies will require timely environmental data obtained through monitoring to properly control impacts.

In addition to providing individual agencies with the necessary information for responding to impacts, a cooperative, intergovernmental monitoring system would facilitate the accomplishment of appropriate response measures. "Whereas an individual agency may be somewhat limited in the range of its mandated responses to a given impact a comprehensive monitoring program may increase the capacity of appropriate agencies to respond to impacts by alerting all concerned agencies to a problem and summoning their collective prerogatives to the problem(s) at hand" (Rockefeller Foundation, 1976). Many impacts affect several different aspects of the environment and fall under more than one governmental jurisdiction. An intergovernmental monitoring system increases the options available for reducing impacts and encourages cooperative implementation of solutions.

\section{EXISTING COMPREHENSIVE EIS MONITORING SYSTEMS}

Only a small number of comprehensive interdisciplinary monitoring systems are known to the author. These systems represent initiatives by a university research institute, by a State legislature, and by a Federal regulatory agency.

\section{INSTITUTE FOR ENVIRONMENTAL STUDIES,} UNIVERSITY OF WISCONSIN

A study to monitor and document the impact of a coal-fired electric power generating plant has been conducted at the University of Wis- 
consin since 1971. The objectives of the study are: (1) documentation of the environmental, economic, and social changes caused by the construction and operation of the plant; (2) accumulation of data and information to improve decisions governing the location, construction, and operation of such plants by environmental regulatory and protection agencies; (3) designing and testing cost-effective techniques for accurate impact assessment; and (4) testing the effectiveness of environmental protection practices (Institute for Environmenal Studies, 1976, p. 14). Data collection was begun prior to plant construction and has continued on a regular basis. Results are stored in a computerized data system for retrieval by study groups. A major effort is underway to integrate and generalize the results from individual research groups. Research results are also being used to develop an impact prediction capability and for developing powerplant siting criteria.

\section{NORTH DAKOTA REGIONAL ENVIRONMENTAL ASSESSMENT PROGRAM (REAP)}

REAP was funded by the North Dakota Legislature in 1975 to provide data and analyses for the legislature and other decisionmakers. The program has been provided $\$ 2$ million from a special trust fund created from the collection of coal severance taxes. The computerized data base being developed by REAP will contain environmental and socioeconomic information for the State. Contemplated uses of the system include monitoring. Monitoring data will be used to identify trends resulting from development activity, to verify impact predictions, and to make decisions on future resource development activities. Input for the data base is provided by State agencies that are already collecting data for their own program needs. Or, if the data are not being collected, responsibility for their collection is assigned to agencies whose responsibilities are most closely related to the data needed. REAP will assist the agencies in obtaining necessary resources to collect the data. REAP is also arranging for access to Federal computerized data bases.

\section{U.S. NUCLEAR REGULATORY COMMISSION}

The U.S. Nuclear Regulatory Commission requires industry to perform "environmental surveillance" of each nuclear power station.
Monitoring requirements are set forth in the technical specifications of the license. Data to be collected are based on the impacts predicted in the EIS. Baseline data acquisition is required prior to plant construction.

The scope of data to be acquired is broad. "The program should cover elements of the ecosystem for which a causal relationship between plant operation and adverse change is established or strongly suggested" (U.S. Nuclear Regulatory Commission, 1975, p. 7).

An interesting component of the monitoring program is "report levels." Report levels are warning notices of impending unacceptable environmental stress. They are set at a level above the normal fluctuations of a given parameter, but low enough to permit remedial action to be taken before significant or irreversible damage has occurred. Report levels are also assessed against "limiting conditions" for operation. Limiting conditions are conditions of plant operation designed to prevent adverse environmental impact. Corrective action to be taken in case limiting conditions are exceeded is specified. The report levels and limiting conditions are mechanisms for triggering appropriate responses to environmental problems as they develop.

There has been some criticism of the monitoring requirements by industry. The criticism centers mainly on the amount of data that must be collected, the cost, and the data's utility (pers. commun. with representative of the Atomic Industrial Forum, January 1977). NRC is taking steps to respond to these problems. The amount of data collection required has been reduced as greater understanding has developed as to which data are most useful as impact indicators.

\section{METHOD OF INVESTIGATION}

The monitoring system described in this report developed from a case study of the needs for monitoring the impacts described in the "Final Environmental Impact Statement: Development of Phosphate Resources in Southeastern Idaho" (U.S. Geological Survey, 1977). This area was selected because future additional resource development and processing are likely due to the growing need for phosphate and the magnitude of the phosphate deposits in the area and because sufficient lead time existed for development of a monitoring sys- 
tem prior to the anticipated expansion of phosphate activities. Also, many government agencies in the area had already recognized a need for monitoring data in order to carry out their responsibilities in the control and mitigation of impacts associated with phosphate development.

Two subprojects, the results of which are to be published elsewhere, were conducted concurrently with the case study to demonstrate the applicability of remote-sensing techniques for acquiring monitoring data. David M. Carneggie and Christopher S. Holm of the U.S. Geological Survey investigated the use of several analytical approaches for monitoring stripmining activities and resultant changes in vegetation and wildlife habitat. Daniel B. Gallagher of the U.S. Geological Survey demonstrated the use of aerial photography for monitoring land-use change.

\section{TO THE USERS OF THIS REPORT}

The report is directed at environmental professionals involved in EIS preparation and Federal, State, and local agencies responsible for dealing with the impacts that result from Federal actions. The methodology in this report for developing comprehensive post-EIS monitoring systems is without precedent and should therefore be regarded as a preliminary effort. The author hopes that this methodology will encourage others to investigate the design and operation of comprehensive monitoring systems and will benefit agencies interested in developing such systems.

\section{ACKNOWLEDGMENTS}

Many individuals and agencies contributed to the development of the monitoring methodology described in this report. R. Kenneth Stolz of the Executive Office of the Governor of Idaho participated in the development of the methodology, co-led the workshop, and coordinated State participation and review. David M. Carneggie, Daniel B. Gallagher, and Christopher S. Holm of the U.S. Geological Survey provided insights developed from their remotesensing subprojects. The following agencies participated in a workshop to define a monitoring system for the Idaho phosphate resource development area, provided descriptions of existing and proposed monitoring efforts, and reviewed this report: U.S. Geological Survey, U.S. Bureau of Land Management, U.S. Fish and Wildlife Service, U.S. Forest Service, U.S. Soil Conservation Service, U.S. Environmental Protection Agency, Idaho Executive Office of the Governor, Idaho Department of Fish and Game, Idaho Department of Health and Welfare, Idaho Department of Water Resources, Idaho Department of Lands, Idaho Department of Agriculture, Idaho Department of Parks and Recreation, Idaho Public Utilities Commission, Idaho Department of Employment, Idaho State Historical Society, and the Southeast Idaho Council of Governments.

\section{IDAHO CASE STUDY}

\section{BACKGROUND}

Phosphate has been mined in southeastern Idaho since 1945 . In 1974, 6.3 million short tons (MMT) of phosphate rock were mined. If mining plans submitted to the Secretary of the Interior are approved, production resulting from proposed Federal lease actions and from the operating mines on Federal lands could reach 15 MMT per year by 2000. This expansion of mining would be accompanied by an increase in the capacity of phosphate processing plants, expansion of transportation and utility networks, and growth in population. As such expansion depends upon several major Federal actions that would have a significant effect on the natural and cultural environments of the area, an environmental impact statement (EIS) was prepared by a Federal interagency task force. The EIS described significant impacts that would result from an expansion of phosphate mining and processing and the measures that could be taken to minimize or prevent environmental degradation. These measures include special lease stipulations, management practices, reclamation techniques, enforcement of regulations, and planning for population growth. Such measures will involve many public agencies whose success in carrying out protective measures will depend in part upon the availability of information necessary for decisionmaking, planning, and regulation enforcement.

\section{MONITORING WORKSHOP}

Recognizing the need for Federal, State, and local agencies to contribute to the design and inception of a comprehensive impact monitoring program, the U.S. Geological Survey held a workshop in Boise, Idaho, March 1976. The State of Idaho was contacted and agreed to 
participate in the workshop. Federal agencies were invited to the workshop by the U.S. Geological Survey; State and local agencies were invited by the State.

\section{PURPOSE}

The purpose of the workshop was to design an optimum monitoring system for measuring the impact of phosphate development in southeastern Idaho. An optimum monitoring system was defined as one in which data collection is limited to the minimum number of essential quantitative indicators that would enable agencies to direct, control, mitigate, and/or prevent impacts. This definition of an optimum monitoring system contrasts with other monitoring systems that attempt to document all environmental changes.

\section{PARTICIPANTS}

The workshop was co-led by Linda Marcus of the U.S. Geological Survey and R. Kenneth Stolz of the State's Division of Budget, Policy Planning, and Coordination. The U.S. Department of the Interior, the U.S. Department of Agriculture, the U.S. Environmental Protection Agency, the State of Idaho, and the Southeast Idaho Council of Governments were represented at the workshop.

\section{APPROACH}

Prior to the workshop a handout entitled "Proposed Methodology for Monitoring Impacts of Phosphate Development" was sent to participants. This paper described the basic assumptions for a monitoring system that the U.S. Geological Survey believed to be desirable and the steps that should be followed in the development of a monitoring system. Included were the assumptions that: (1) an optimum monitoring system limits data collection to the minimum number of data types that are essential; (2) the frequency of data collection, number of monitoring stations, and level of detail or scale should be reduced to the most economical and efficient system possible; and (3) a data need should be justifiable on the basis of its practical value to agencies in decisionmaking, planning, and regulation and enforcement.

The methodology to be tested at the workshop was limited to a procedure for designing a monitoring system; it consisted of the following steps:

Step 1.-Predict the potential impacts. (This step was accomplished by the EIS task force prior to the workshop.)

Step 2.-Define the objectives of the monitoring system.

Step 3.- Select key impacts that should be monitored.

Step 4.-Determine data needs for each impact to be monitored; determine data needs for measuring the activities causing the impact.

Step 5.-Determine data availability and identify data gaps in existing data collection efforts.

The steps were carried out primarily through the use of worksheets and matrices.

\section{RESULTS FROM THE WORKSHOP}

\section{STEP 1. PREDICTION OF IMPAGTS}

Most of the impacts likely to occur had already been assessed by the interagency task force prior to the workshop. Many agencies represented at the workshop had been involved in preparation or review of the predicted impacts described in the draft EIS and, therefore, most participants were knowledgeable of the impacts of increased phosphate development. The impact(s) and activity(ies) causing the impact are identified for each environmental parameter.

TABLE 1.-Summary of impacts predicted in the EIS

[Activity causing impact is given in parentheses when not known if activity will occur]

\begin{tabular}{lrr}
\hline Environmental parameter & Impact & Activity causing impact \\
\hline Geology and minerals & Mineral consumption and loss: & Extraction of ore. \\
Consumption of 25-38\% of & Backfilling or reclamation over \\
phosphate reserves in area; & unmined resources. \\
& consumption of other minerals. & \\
& $\begin{array}{c}\text { Resources made unrecoverable or } \\
\text { recovery inhibited. }\end{array}$ & \\
\hline
\end{tabular}


TABLE 1.-Summary of impacts predicted in the EIS-Continued

[Activity causing impact is given in parentheses when not known if activity will occur]

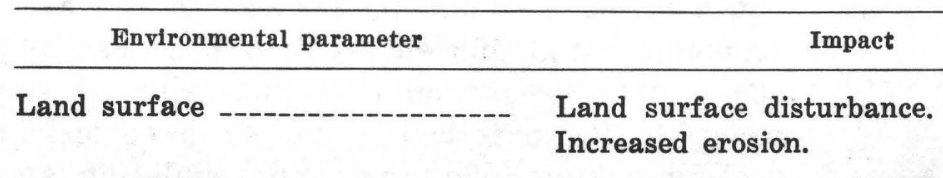

Land surface distur
Increased erosion.
Activity causing impact

Excavation of mine pit.

Waste dump storage.

Grading for roads, buildings, etc.

Reclamation.

Offsite housing construction, roadbuilding, etc.
Removal of overburden, scalping site.

Emissions from processing facilities.
Lowered soil productivity.

Localized soil contamination.
Same as activities under "Land surface," plus:

Scalping site.

Construction of transportation network.
Ground-water supply
Changes in water flow patterns such

as decreased infiltration and velocities, increased erosion of streambeds and banks, reduction or increase in amount of flow.
Localized change in ground-water recharge and discharge relationships.

Localized water level lowering.
Excavation of mine pit.

Backfilling.

Waste storage.

Water consumption for phosphate processing.
Water quality
Increased sediment yield, especially during spring runoff.

Chemical contamination.

Radiation release.

Eutrophication from increased nitrogen and phosphorus levels.
Excavation of mine pit.

Backfilling or reclamation.

Scalping site.

Construction of roads and facilities.

Extraction of ore.

Processing of ore.

Extraction of ore.

Water use

Increased water consumption by
municipalities and industries.

Employment of workers/population growth.

Phosphate processing.

(Hydroelectric energy production expansion.)

Air quality

Chemical contaminants:

Phosphate processing.

$\mathrm{SO}_{2}$, particulates, trace elements.

Fluorine, fluorosis in livestock.

Particulates (fugitive dust).

Radiation release.

Emissions from settling ponds.

Extraction and hauling of ore, waste dumps.

Vegetation

Removal, disturbance of vegetation.

Change in vegetation.

Localized chemical contamination.

Fugitive dust deposited, reduction in plant vigor.

Same as "Land surface."

Revegetation/reclamation, land surface disturbance, land-use change.

Same as "Air quality."

Wildlife

Loss of habitat, displacement.

Decreased productivity.

Big game: disruption of migration routes, loss or disturbance of calving areas, and critical winter habitat.

Increased roadkills.

Mining activities, scalping site, railroad, and roadbuilding.

Excavation of mine pit and resultant highwall.

Vehicular movement, transportation of people and materials. 
TABLE 1.-Summary of impacts predicted in the EIS-Continued

[Activity causing impact is given in parentheses when not known if activity will occur]

$\frac{\text { Environmental parameter }}{\text { Threatened and endangered }}$ species.

Impact

Peregrine falcon: abandonment of existing nesting sites.

Whooping crane: loss of potential habitat.
Activity causing impact

Mining activities : replacement of habitat of prey species and disturbance during nesting and courtship periods in early spring and late winter.

Mining and associated activities.

Fisheries

Pollution of habitat by sediment, toxic substances, and airborne materials.

Reduction of fishery populations.

Mining activities.

Processing activities.

Construction of transportation networks.

Land use

Land-use change:

Increases in industrial, transportation, utilities, residential, and commercial land uses.

Decreases in rangeland, agricultural land, natural areas.

Increased barren lands and/or reclaimed lands.

\section{Mining activities.}

Processing activities.

Expansion of transportation and utility networks.

Employment of workers/population growth.

\section{Population growth.}

Increased housing demand.

Increased demand for public facilities and services.

Increased fiscal government costs.
Transportation and utilities.
Increased traffic volume.

Accelerated deterioration of roadways.

Expansion of transportation and utility networks.

Increased demand for power for phosphate processing, for light industry, for commercial growth, and for residential growth.

\section{Recreation}

\section{Archeologic and} historic values.
Reduced quality of outdoor recreation: dust, odor, smoke, noise, air pollution, visual degradation, land surface disturbance, and loss of wildlife habitat.

Increased demand and decreased opportunity for outdoor recreation experiences.

Reduction in hunting and fishing opportunity.

Greater access to remote areas, loss of natural phenomena and secluded character.

Damage, destruction of petroglyphs.

Destruction of historic visual character of cultural resources.

Increased vandalism.

\section{Employment of workers for mining and processing operations (and induced population growth).}
Transportation of people and materials for mining and processing.
Employment of workers (and induced population growth).

Mining and processing activities.

Transportation and utility networks.

Employment of workers (and induced population growth).

\footnotetext{
Excavation of mine pit.

Construction of haul roads and railroads.

Construction of processing plant.

Employment of workers. (and induced population growth).
} 
TABLE 1.-Summary of impacts predicted in the EIS-Continued

[Activity causing impact is given in parentheses when not known if activity will occur]

\begin{tabular}{ccc}
\hline Environmental parameter & Impact & Activity causing impact \\
\hline Aesthetic values -1 mining and processing & activities. \\
alteration of visual character. & $\begin{array}{c}\text { Degradation of clean air, clear } \\
\text { water. } \\
\text { Introduction of more industrial, } \\
\text { commercial, and urban elements. } \\
\text { Reduction in area of predominantly } \\
\text { rural or natural character. } \\
\text { Increase in area of disturbed or } \\
\text { barren land. }\end{array}$ \\
\hline
\end{tabular}

\section{STEP 2. MONITORING OBJEGTIVES}

Participants were asked to complete a worksheet prior to the workshop which asked for the following information: (1) a description of the agency's areas of concern that pertain to phosphate operations; (2) their objectives for monitoring (what a monitoring program should provide); and (3) the use and value of monitoring information (what decisions monitoring information would help them make, how it would help them plan, what regulation it woud help them enforce). Agency representatives presented this information at the workshop. Table 2 is an example of a monitoring objectives worksheet. (The complete set of worksheets may be obtained from: U.S. Geological Survey, 760 National Center, Reston, VA 22092.)

\section{TABLE 2. Example of a monitoring objectives worksheet}

[The source of information is given in parentheses below the agency name. Data in the last column were given in response to the question, "How would your agency use monitoring information?" $\mathrm{D}=$ decisionmaking; $\mathrm{P}=\mathrm{planning} ; \mathrm{R}=\mathrm{regulation}$ and en. forcement; $\mathrm{O}=$ other, specify ]

\begin{tabular}{lcccc}
\hline Agency & Areas of concern & Objectives & Use and value \\
\hline $\begin{array}{l}\text { U.S. Department } \\
\text { of Agriculture, }\end{array}$ & $\begin{array}{c}\text { Erosion and sedimentation prob- } \\
\text { lems and vegetative restoration }\end{array}$ & $\begin{array}{c}\text { Identify land-use changes asso- } \\
\text { ciated with increased mining ac- }\end{array}$ & $\begin{array}{r}\text { P. Information would be furnished } \\
\text { to local conservation districts }\end{array}$ \\
$\begin{array}{llll}\text { Soil Conservation } \\
\text { Service. }\end{array}$ & $\begin{array}{l}\text { of strip-mined areas and spoils. } \\
\text { Land use changes industrial and } \\
\text { urban-related to mining activities. }\end{array}$ & $\begin{array}{c}\text { Identify active erosion and sedi- } \\
\text { mentation areas. }\end{array}$ & and county/city planning and \\
& & Identify deterioration of vegetation. agencies. Assist local & landowners with plans to con- \\
& & & trol soil erosion and sedimen- \\
& & & tation.
\end{tabular}

Environmental Protection

Agency.
All activities which have direct and/or indirect impacts on air and water quality, solid wastes, radiation, and applicable regulations.
Provide a good baseline on the present activities (conditions?) prior to further expansions.

D. Whether to allow phosphate fertilizer processing plant to be constructed pursuant to sig nificant air quality deterioration regulations; sewer treatment plant expansions.

P. Water (industrial) discharge permits.

R. Significant air quality deterioration; ambient air quality standards; State water qual. ity and air regulations.

\section{U.S. Geological}

Survey,

Conservation

Division,

Pocatello, Idaho.

\section{Supervision of mining operations on Federal mineral leases, includ- ing review and approval of min- ing operations to insure safe and efficient operations, protec- tion of the environment, maxi- mum efficient recovery of the phosphate resource, compliance with all applicable laws and regulations, and correct royalty payments to the United States or Indian lessors.}

Provide information which could enable the mining supervisor's office to better manage and supervise mining operations on Federal land. Provide baseline environmental studies to evaluate impacts at a future date.

Compare the level of impact that results with different methods of dump construction and reseeding techniques.

Determine the extent to which different conditions reduce nonpoint pollution sources.

Determine long-term impact on water resources from nutrient loading, suspended sediment, radioactive contaminants, and heavy metals.
D. Evaluating impacts of proposed mining operations.

R. 30 CFR 231, 43 CFR 23 (Code of Federal Regulations).

o. Supervising mineral lease developments. 
Several monitoring objectives were defined. Although differences of opinion were evident, the following primary objectives were supported by most of the participants.

Baseline data.-At least eight agencies identified acquisition of baseline data as an objective of a monitoring system. It appears that many agencies feel they are greatly hindered in carrying out their responsibilities relating to phosphate development by the lack of baseline data. Baseline data in the context of a monitoring system are collected prior to the start of actions that cause the impacts. Baseline data provide a historic record of environmental conditions for comparison with impact levels. ${ }^{2}$

Control and management of impacts.-The objective of responding to impacts as they occur, which is perhaps the most urgent need of a monitoring system, was strongly emphasized. Collectively, the agencies have considerable potential to control or regulate the level of impacts. However, agencies must obtain data that support their decisionmaking and obtain feedback over time as to the success of their decisions in order to further modify the impact of current and future phosphate activities. A monitoring program that provides feedback when unfavorable environmental trends emerge would allow agencies to develop appropriate responses before critical situations develop.

Warning of critical impact levels.-A properly designed system should indicate that a particular environmental parameter is approaching a critical threshold. Impact levels should be established that would trigger immediate notification of critical conditions.

Documentation of impacts.-The objective of documenting actual impacts would have great utility by creating a permanent record of the magnitude and nature of the impacts of phosphate development. This knowledge would be invaluable for improving prediction in future EIS's.

Model verification.-Documentation of impacts would provide the cause and effect data for empirical verification or validation of various predictive models of action/impact relationships.

STEP 3. IMPACTS SELECTED FOR MONITORING

Activity/impact matrices were used for considering the various impacts anticipated from

\footnotetext{
${ }^{2}$ A quantitative or qualitative evaluation of an impact parameter.
}

increased phosphate production. It was intended that participants would use the matrices to identify which impacts should be monitored. However, the matrix format proved to be excessively time consuming within the constraints of a 2-day workshop and it was consequently abandoned. Instead, a list of impacts that should be considered for monitoring was generated by group discussion. Then, workshop participants having similar concerns and responsibilities divided into work groups. Each work group considered a set of impacts and revised them. These same work groups then generated the worksheets for steps 4 and 5 .

\section{STEP 4. DATA NEEDS}

Each work group completed a data-needs worksheet for each impact that the group felt should be monitored. Table 3 is an example of a data-needs worksheet. (The complete set of worksheets may be obtained from the U.S. Geological Survey.) The following information was requested: (1) quantitative indicator suitable for measuring the impact; (2) alternative indicators that may also be acceptable; (3) recommended collection frequency of the data; (4) minimum acceptable collection frequency; (5) recommended format, such as maps, tables, text; (6) level of detail or accuracy; (7) location(s) and geographic area where data should be collected; (8) potential methods of collection; and (9) value or justification for collecting the data.

\section{STEP 5. DATA AVAILABILITY}

Work groups filled out data-availability worksheets to determine if the data presently being collected are acceptable for the monitoring system in terms of frequency of collection. Table 4 is an example of a data-availability worksheet. (The complete set of worksheets may be obtained from the U.S. Geological Survey.)

It appears that many of the data needs could be met within existing data-collection efforts. Inadequacies occur primarily in the frequency of collection and location or geographic area. Generally, data-collection sites were not located specifically to measure the impacts of phosphate mining and processing. Likewise, the frequency and timing of data collection may not have been established to obtain data when there is the greatest likelihood of phosphaterelated impacts occurring (for example, during 
TABLE 3.-Example of compilation of data-needs worksheet

\begin{tabular}{|c|c|c|c|c|c|c|c|}
\hline Impact & $\begin{array}{l}\text { Indicator } \\
\text { (alternative } \\
\text { indicators) }\end{array}$ & $\begin{array}{l}\text { Collection } \\
\text { frequency } \\
\text { (min. } \\
\text { acceptable } \\
\text { frequency) }\end{array}$ & Format & $\begin{array}{l}\text { Level of } \\
\text { detail, } \\
\text { accuracy }\end{array}$ & $\begin{array}{l}\text { Location } \\
\text { and } \\
\text { geographic } \\
\text { area }\end{array}$ & $\begin{array}{l}\text { Potential } \\
\text { methods } \\
\text { of } \\
\text { collection }\end{array}$ & Value ${ }^{1}$ \\
\hline $\begin{array}{l}\text { 1. Land } \\
\text { surface } \\
\text { disturbance: } \\
\text { Topographic } \\
\text { change. } \\
\text { Moving } \\
\text { dirt. }\end{array}$ & $\begin{array}{l}\text { Acreage } \\
\text { disturbed } \\
\text { and } \\
\text { location: } \\
\text { a. Roads } \\
\text { b. Pits } \\
\text { c. Dump } \\
\text { d. Plants } \\
\text { e. Water- } \\
\text { control } \\
\text { struc- } \\
\text { tures- } \\
\text { ditches, } \\
\text { dams, } \\
\text { ponds? } \\
\text { (Length of } \\
\text { disturb- } \\
\text { ance.) }\end{array}$ & $\begin{array}{l}\text { Once per } \\
\text { year. } \\
\text { (Once per } \\
\text { year.) }\end{array}$ & $\begin{array}{l}\text { Map and } \\
\text { table. }\end{array}$ & $\begin{array}{r} \pm 5 \% \text { and } \\
\text { std. map } \\
\text { accuracy. }\end{array}$ & $\begin{array}{l}\text { (Entire EIS } \\
\text { study } \\
\text { area) land } \\
\text { surface } \\
\text { disturbed } \\
\text { by } \\
\text { phosphate } \\
\text { exploration, } \\
\text { mining, } \\
\text { processing, } \\
\text { and } \\
\text { expanded } \\
\text { population. }\end{array}$ & $\begin{array}{l}\text { 1. Air } \\
\text { photos } \\
\text { (reclama- } \\
\text { tion } \\
\text { probably } \\
\text { needs } \\
\text { to be } \\
\text { monitored } \\
\text { on the } \\
\text { ground). } \\
\text { 2. Satellite } \\
\text { data, } \\
\text { company } \\
\text { and other } \\
\text { agencies } \\
\text { data. }\end{array}$ & \\
\hline $\begin{array}{l}\text { 2. Geology } \\
\text { and } \\
\text { minerals: } \\
\text { Nonre- } \\
\text { newable } \\
\text { resource } \\
\text { consump- } \\
\text { tion. }\end{array}$ & $\begin{array}{l}\text { Tons of ore } \\
\text { and \% } \\
\mathrm{P}_{2} \mathrm{O}_{5} \text { or } \\
\% \text { P plus } \\
\text { other } \\
\text { elements. }\end{array}$ & $\begin{array}{l}\text { Monthly. } \\
\text { (Monthly.) }\end{array}$ & $\begin{array}{l}\text { Same as } \\
\text { company } \\
\text { production } \\
\text { report. }\end{array}$ & $\begin{array}{l} \pm 1 \text { ton. } \\
\pm 1 \%\end{array}$ & $\begin{array}{l}\text { All } \\
\text { phosphate. } \\
\text { producing } \\
\text { areas } \\
\text { (leases } \\
\text { and } \\
\text { patented } \\
\text { land). }\end{array}$ & $\begin{array}{l}\text { Company } \\
\text { production } \\
\text { reports } \\
\text { and } \\
\text { interviews. }\end{array}$ & \\
\hline
\end{tabular}

${ }^{1}$ AUthor's note : No information supplied by work groups. 
TABLE 4.-Example of compilation of data-availability worksheets

\begin{tabular}{|c|c|c|c|c|c|c|c|}
\hline $\begin{array}{l}\text { Impact } \\
\text { indicator }\end{array}$ & $\begin{array}{l}\text { Period } \\
\text { collected }\end{array}$ & Agency & $\begin{array}{l}\text { Collection } \\
\text { frequency }\end{array}$ & Format & Accuracy & Location & $\begin{array}{l}\text { Method of } \\
\text { collection }\end{array}$ \\
\hline $\begin{array}{l}\text { Land } \\
\text { surface } \\
\text { disturbance } \\
\text { acreage. }\end{array}$ & $?-1976$ & $\begin{array}{c}\text { U.S. Geo- } \\
\text { logical } \\
\text { Survey. }\end{array}$ & Annually. & $\begin{array}{l}\text { Maps, tables, } \\
\text { narrative } \\
\text { reports. }\end{array}$ & Unknown. & $\begin{array}{l}\text { All Federal } \\
\text { mineral } \\
\text { leases. }\end{array}$ & $\begin{array}{l}\text { Ground } \\
\text { surveys, } \\
\text { aircraft } \\
\text { photogra- } \\
\text { phy, annual } \\
\text { operations } \\
\text { report. } \\
\text { Alternatives : } \\
\text { satellite } \\
\text { and high- } \\
\text { altitude } \\
\text { aircraft } \\
\text { imagery. }\end{array}$ \\
\hline $\begin{array}{l}\text { Tons of } \\
\text { phosphate } \\
\text { mined. }\end{array}$ & $1916-76$ & $\begin{array}{c}\text { U.S. Geo- } \\
\text { logical } \\
\text { Survey. }\end{array}$ & Annually. & $\begin{array}{l}\text { Maps, tables, } \\
\text { narrative } \\
\text { reports. }\end{array}$ & Variable. & $\begin{array}{l}\text { Federal } \\
\text { mineral } \\
\text { leases. }\end{array}$ & $\begin{array}{l}\text { Annual } \\
\text { operations } \\
\text { report. }\end{array}$ \\
\hline $\begin{array}{l}\text { Acreage } \\
\text { of soil } \\
\text { disturbance; } \\
\text { erosion } \\
\text { loss; } \\
\text { trace } \\
\text { element } \\
\text { and } \\
\text { radioactive } \\
\text { concentra- } \\
\text { tions of } \\
\text { soil } \\
\text { surface } \\
\text { near } \\
\text { processing } \\
\text { plants; } \\
\text { acreage } \\
\text { retop- } \\
\text { soiled. }\end{array}$ & Not being collected & -- - - - - - - & - - - & ---n-- & $---1-4$ & - & - - - - \\
\hline $\begin{array}{l}\text { Vegetation } \\
\text { type }\end{array}$ & 1975. & $\begin{array}{l}\text { Co-op } \\
\text { project: } \\
\text { Idaho, } \\
\text { National } \\
\text { Aeronautics } \\
\text { and Space } \\
\text { Admin., } \\
\text { U.S. } \\
\text { Geological } \\
\text { Survey, } \\
\text { U.S. } \\
\text { Forest } \\
\text { Service, } \\
\text { Pacific } \\
\text { NW Reg. } \\
\text { Comm. }\end{array}$ & Baseline. & $\begin{array}{l}\text { Maps, tables, } \\
\text { summaries. }\end{array}$ & $\begin{array}{l}90 \%+ \\
1-40 \text { acre } \\
\text { min. }\end{array}$ & SE Idaho. & $\begin{array}{l}\text { Landsat } \\
\text { analysis, } \\
\text { small and } \\
\text { medium } \\
\text { scale } \\
\text { aircraft } \\
\text { imagery } \\
\text { and } \\
\text { ground } \\
\text { sampling. }\end{array}$ \\
\hline
\end{tabular}

a major storm or spring runoff). Some additional data need to be collected.

\section{POST-WORKSHOP ANALYSES AND SYNTHESIS}

The information generated at the workshop represents a valuable first cut at designing a monitoring system. Because the time available at the workshop permitted only brief reporting of the conclusions generated by the work groups, it was necessary to synthesize this information into a monitoring system after the workshop. The synthesis was conducted primarily by the author with the aid of workshop participants providing specific information and review of a preliminary draft of this report. Information supplied by participants after the workshop included existing and proposed data-collection efforts, relevant research, and existing interagency institutional structures. This report incorporates review comments on the preliminary draft.

The development of a monitoring system is an iterative process. A postworkshop iteration is presented that refines and integrates the 
Phases of mining activity

Impacts

\begin{tabular}{|c|c|c|c|c|}
\hline \multicolumn{2}{|c|}{ Exploration } & \multicolumn{3}{|c|}{ Construction } \\
\hline 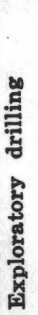 & 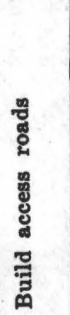 & 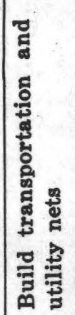 & 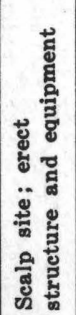 & 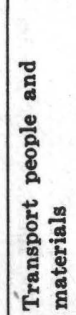 \\
\hline
\end{tabular}

Phosphate consumption/loss
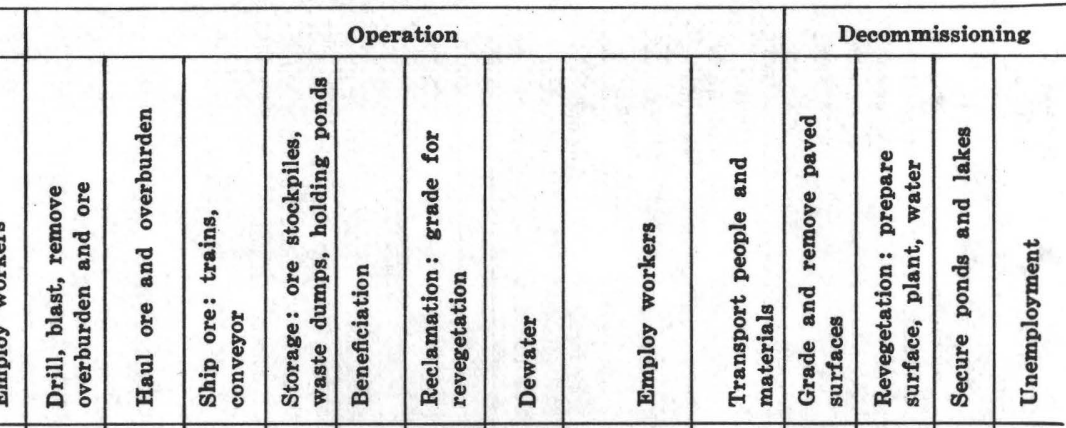

Land surface disturbance/soil loss

Air quality:

Fugitive dust

Water quality:

Sediment yield increase

Chemical contamination

Biological health reduction

เง Water supply reduction

\begin{tabular}{lllll|l|l|l|l|l}
\hline & 0 & 0 & & & & & & & \\
\hline & $\bullet$ & $\bullet$ & $\bullet$ & $\bullet$ & $\bullet$ & $\bullet$ & $\bullet$
\end{tabular}

Water supply reduction

Radiation release

Wildlife:

Endangered species population loss

Roadkills and obstruction of migration

Displacement of resident species

Aquatic:

Fishkills, reduced species diversity

Land use/land cover change

Population growth

Fiscal government costs/revenues increase

Quality of life deterioration

Employment level changes

Transportation and utility networks expansion

Archeologic site destruction

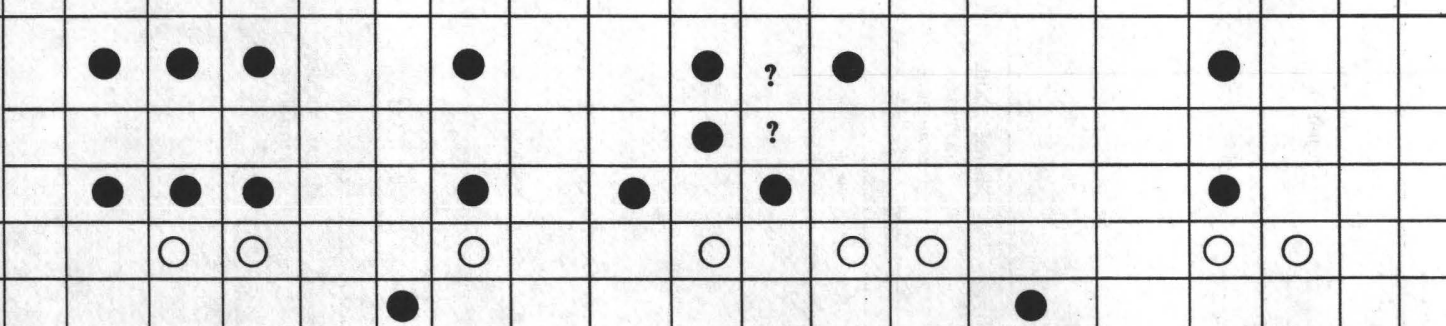

\begin{tabular}{|c|c|c|c|c|c|}
\hline • & & 0 & & $\bullet$ & \\
\hline & 0 & & $\bullet$ & $\bullet$ & 0 \\
\hline 0 & & 0 & & 0 & \\
\hline
\end{tabular}

$\bullet$

0

0 .


TABLE 6.-Activity/impact matrix: Processing phosphate ore

[Key : O-major impact likely to occur; - -impact should be monitored; ?-not known if impacts result]

\begin{tabular}{|c|c|c|c|c|c|c|c|c|c|c|c|}
\hline & \multicolumn{11}{|c|}{ Phases of processing activity } \\
\hline & \multicolumn{6}{|c|}{ Construction } & \multicolumn{5}{|c|}{ Production } \\
\hline & 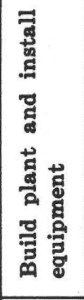 & 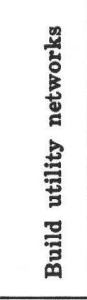 & 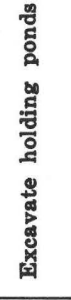 & 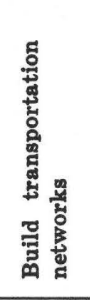 & 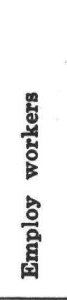 & 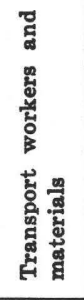 & 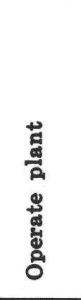 & 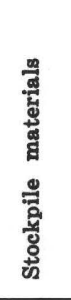 & 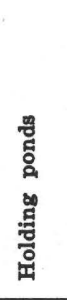 & 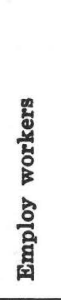 & 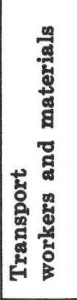 \\
\hline \multicolumn{12}{|l|}{ Processed phosphate } \\
\hline Land surface disturbance/soil loss & $\mathrm{O}$ & $\mathrm{O}$ & $\mathrm{O}$ & $\mathrm{O}$ & & & & $\mathrm{O}$ & & & \\
\hline $\begin{array}{l}\text { Air quality: } \\
\text { Fugitive dust }\end{array}$ & $\mathrm{O}$ & & & & & $?$ & $\mathrm{O}$ & $\mathrm{O}$ & $\mathrm{O}$ & & \\
\hline Chemical contamination & & & & & & & O & & O & & \\
\hline $\begin{array}{l}\text { Water quality: } \\
\text { Sediment yield increase }\end{array}$ & O & O & O & $\mathrm{O}$ & & & & $\mathrm{O}$ & & & \\
\hline \multicolumn{12}{|l|}{ Chemical contamination } \\
\hline Water use increase & & & $\mathrm{O}$ & & $\mathrm{O}$ & & $\mathrm{O}$ & & $\mathrm{O}$ & O & \\
\hline Radiation release & & & & & & & $\mathrm{O}$ & O & 0 & & \\
\hline \multicolumn{12}{|l|}{ Vegetation/soil contamination } \\
\hline \multicolumn{12}{|l|}{$\begin{array}{l}\text { Wildlife: } \\
\quad \text { Roadkills and obstruction } \\
\end{array}$} \\
\hline \multicolumn{12}{|l|}{$\begin{array}{l}\text { Aquatic life: } \\
\text { Fishkills, reduced species diversity. }\end{array}$} \\
\hline Land use/land cover change & $\mathrm{O}$ & $\mathrm{O}$ & $\mathrm{O}$ & $\mathrm{O}$ & & & & 0 & O & & \\
\hline \multicolumn{12}{|l|}{ Population growth } \\
\hline \multicolumn{12}{|l|}{ Fiscal government costs/revenues increase } \\
\hline \multicolumn{12}{|l|}{$\begin{array}{l}\text { Quality of life deterioration } \\
\text { (housing, education, public safety, etc.) }\end{array}$} \\
\hline \multicolumn{12}{|l|}{ Employment level changes } \\
\hline Transportation and utility networks expansion & & $\mathrm{O}$ & & $\mathrm{O}$ & & $\mathrm{O}$ & $\bigcirc$ & & & & $\mathrm{O}$ \\
\hline Energy demand increase & & & & & & $\mathrm{O}$ & $\mathrm{O}$ & & & & O \\
\hline
\end{tabular}


components of the monitoring system produced thus far. Additional iterations to be developed by the participating agencies are necessary prior to implementation of the monitoring system.

Three products were generated from the workshop experience that illustrate the monitoring system: (1) an activity/impact matrix, (2) a data-needs table, and (3) a generalized activity/impact schedule.

\section{ACTIVITY/IMPACT MATRICES}

Although matrices were found to be cumbersome workshop tools, revised matrices are used because they concisely display the multiple relationships of activities and impacts. The matrices aid selection of the impacts that should be monitored because all activities contributing to a particular impact are identifiable, and, likewise, all impacts resulting from a particular activity are easily identifiable. The matrix is also a useful reference for eliminating overlap among impacts selected for monitoring and for selecting alternative impacts to monitor in those cases where collection of a particular type of data is not feasible.

Activities and impacts are described for phosphate mining and processing (tables 5 and 6 ). The activities are grouped by phases on the activity axis. For example, mining activities are grouped under exploration, construction, operation, and decommissioning phases. This grouping is useful for establishing a general time frame. Impacts are specifically identified on the impact axis. Selection of impacts to be monitored is done by circling impacts ( $O$ is used in tables 5 and 6 ). Future iterations may alter the final selection of impacts to be monitored; selection of impacts should be based on the methodology described in pages 26-38.

\section{DATA-NEEDS TABLE}

The data-needs table (table 7) is a modified version of the data-needs worksheets produced at the workshop. Changes were made to eliminate overlap of similar data types, to eliminate data that were not justifiable or pertinent to monitoring objectives, and to add additional description as needed.

The information provided in the data-needs table for each impact to be monitored includes: (1) impact indicators - the particular type of data that is measured to determine impact level; (2) the timing of the impact-the rela- tionship of the timing of the impact to phases of the action; (3) agency responsible for collection-agency (ies) that has responsibility for collecting the data because of its program responsibilities, or because the data are within its area of expertise; (4) location or site where data are to be measured; (5) collection frequency; (6) collection method; (7) use of data-a justification of how the monitoring data will assist agencies in controlling impacts to ensure that the type, frequency, location, and method of data collection will be suitable for enforcement of pertinent rules and regulations; and (8) remarks. The information in this table is general; subsequent iterations can be expected to pinpoint data-collection sites and data-collection schedules.

Monitoring data are used in the following ways. The data identify the type of impact that occurs, where the impact occurs, when the impact occurs and its duration, and the level of impact. These data can then be correlated with the type, level, location, and timing of the activities causing the impacts. It is not necessary to obtain data on every activity to establish correlation with impacts. A few indicators of the magnitude, timing, and location of the action may be sufficient.

\section{ACTIVITY/IMPACT SCHEDULE}

The activity/impact schedule relates the timing of activities and impacts. Figure 1 is an example of a generalized impact schedule for a mine and for a processing plant. Impacts are not necessarily limited to the duration of the activity causing the impact; impacts may persist after the activity causing the impact has ceased. This should be taken into account when the timespan of a monitoring system is decided.

A schedule of the assumed production from mines in the EIS study area is presented in figure 2. An indication of the impact level likely to result can be obtained by relating the activity/impact schedule to a production level schedule. This enables the user of a monitoring system to predict when critical impact levels are most likely to occur and to alert agencies to those time periods when impact control responses are most likely to be needed.

Another use of the activity/impact schedule is to relate the schedules and production levels 
TABLE 7.-Monitoring data needs

\begin{tabular}{|c|c|c|c|c|c|c|c|}
\hline $\begin{array}{l}\text { Impacts and } \\
\text { impact indicator (s) }\end{array}$ & $\begin{array}{l}\text { Timing of } \\
\text { impact }\end{array}$ & $\begin{array}{l}\text { Agency responsible } \\
\text { for collection }\end{array}$ & $\begin{array}{l}\text { Location or site } \\
\text { where data are } \\
\text { to be measured }\end{array}$ & $\begin{array}{l}\text { Collection } \\
\text { frequency }\end{array}$ & $\begin{array}{l}\text { Collection } \\
\text { method }\end{array}$ & Use of data & Remarks \\
\hline $\begin{array}{l}\text { Phosphate } \\
\text { consumption/ } \\
\text { loss } \\
\text { Tons of ore and } \\
\text { percent } \mathrm{P}_{2} \mathrm{O}_{5} \\
\text { mined. } \\
\text { Estimate tons of } \\
\text { ore no longer } \\
\text { recoverable due to } \\
\text { filling. }\end{array}$ & \begin{tabular}{l}
\multicolumn{1}{c}{ Mining: } \\
Operation \\
and decom- \\
missioning \\
phases.
\end{tabular} & $\begin{array}{l}\text { U.S. Geological } \\
\text { Survey, } \\
\text { Conservation } \\
\text { Division. }\end{array}$ & Each minesite. & $\begin{array}{l}\text { Tons of ore } \\
\text { mined: } \\
\text { Monthly. } \\
\text { Tons of ore } \\
\text { made unre- } \\
\text { coverable: } \\
\text { Annually. }\end{array}$ & $\begin{array}{l}\text { Tons of ore } \\
\text { mined: Com- } \\
\text { pany reports } \\
\text { to regulator. } \\
\text { Tons of ore } \\
\text { unrecoverable: } \\
\text { Field study. }\end{array}$ & $\begin{array}{l}\quad \text { Regulation and } \\
\text { enforcement: } \\
\text { Enforce Mineral } \\
\text { Leasing Act; } \\
\text { determine amount } \\
\text { of royalties due } \\
\text { Federal and State } \\
\text { Government. } \\
\text { Planning: } \\
\text { Plan and schedule } \\
\text { future resource } \\
\text { development. } \\
\text { Other: Correlate } \\
\text { level of mining } \\
\text { activity with } \\
\text { resultant impact } \\
\text { levels; predict } \\
\text { future impacts. }\end{array}$ & $\begin{array}{l}\text { Data may be } \\
\text { confidential; } \\
\text { obtain indus- } \\
\text { try approval } \\
\text { for public } \\
\text { disclosure. }\end{array}$ \\
\hline $\begin{array}{l}\text { Phosphate } \\
\text { processed } \\
\text { Tons of } \\
\text { phosphate ore } \\
\text { processed. }\end{array}$ & $\begin{array}{l}\text { Processing: } \\
\text { Operation } \\
\text { phase. }\end{array}$ & $\begin{array}{l}\text { U.S. } \\
\text { Environmental } \\
\text { Protection } \\
\text { Agency. }\end{array}$ & $\begin{array}{l}\text { Each } \\
\text { processing plant. }\end{array}$ & Monthly. & $\begin{array}{l}\text { Industry } \\
\text { reports. }\end{array}$ & $\begin{array}{l}\text { Correlation of } \\
\text { level of processing } \\
\text { activity with level } \\
\text { of air, water, soil, } \\
\text { and vegetation } \\
\text { contamination; } \\
\text { value for future } \\
\text { impact predictions. }\end{array}$ & $\begin{array}{l}\text { Data may be } \\
\text { confidential; } \\
\text { obtain indus- } \\
\text { try approval } \\
\text { for public } \\
\text { disclosure. }\end{array}$ \\
\hline $\begin{array}{l}\text { Land surface } \\
\text { disturbance from } \\
\text { minesites } \\
\text { Acreage and } \\
\text { location of } \\
\text { disturbance from } \\
\text { mining: pits, } \\
\text { dumps, access } \\
\text { roads, railroads, } \\
\text { clearcutting, and }\end{array}$ & $\begin{array}{l}\text { Mining: } \\
\text { All phases. }\end{array}$ & $\begin{array}{l}\text { U.S. Geological } \\
\text { Survey; Bureau } \\
\text { of Land } \\
\text { Management; } \\
\text { U.S. Forest } \\
\text { Service. }\end{array}$ & Minesites. & Annually. & $\begin{array}{l}\text { Remote } \\
\text { sensing at } \\
1: 24,000 \text { scale. }\end{array}$ & $\begin{array}{l}\text { Regulation and } \\
\text { enforcement: En- } \\
\text { force compliance } \\
\text { with terms } \\
\text { of lease and } \\
\text { reclamation } \\
\text { standards of } \\
\text { surface manage- } \\
\text { ment agency. }\end{array}$ & $\begin{array}{l}\quad \text { Permits } \\
\text { correlation of } \\
\text { acreage } \\
\text { disturbed, } \\
\text { reclaimed, } \\
\text { and level of } \\
\text { sediment yield. }\end{array}$ \\
\hline
\end{tabular}

clearcutting, and

administrative

maintenance areas. 
TABLE 7.-Monitoring data needs-Continued

\begin{tabular}{|c|c|c|c|c|c|c|c|}
\hline $\begin{array}{l}\text { Impacts and } \\
\text { impact indicator }(\mathrm{s})\end{array}$ & $\begin{array}{l}\text { Timing of } \\
\text { impact }\end{array}$ & $\begin{array}{l}\text { Agency responsible } \\
\text { for collection }\end{array}$ & $\begin{array}{l}\text { Location or site } \\
\text { where data are } \\
\text { to be measured }\end{array}$ & $\begin{array}{l}\text { Collection } \\
\text { frequency }\end{array}$ & $\begin{array}{l}\text { Collection } \\
\text { method }\end{array}$ & Use of data & Remarks \\
\hline
\end{tabular}

Land surface dis-

turbance from mine-

sites-Continued:

Acreage and loca-

tion of reclamation:

Acreage backfilled, re-

contoured, revegetated,

returned to pro-

ductive use. Length

of time to reclaim.

\begin{tabular}{|c|c|c|c|c|c|c|}
\hline $\begin{array}{l}\text { Vegetation/soil } \\
\text { contamination } \\
\text { Concentration of } \\
\text { cadmium, chro- } \\
\text { mium, fluorine, } \\
\text { lithium, selenium, } \\
\text { uranium, vana- } \\
\text { dium, and zinc in } \\
\text { vegetation. }\end{array}$ & $\begin{array}{l}\text { Processing: } \\
\text { Operation } \\
\text { phase. }\end{array}$ & $\begin{array}{l}\text { Idaho Depart- } \\
\text { ment of Health } \\
\text { and Welfare; } \\
\text { Idaho Depart- } \\
\text { ment of } \\
\text { Agriculture. }\end{array}$ & $\begin{array}{l}\text { Samples taken } \\
\text { within } 1 \text { mile of } \\
\text { processing plant. }\end{array}$ & $\begin{array}{l}\text { Monthly } \\
\text { during plant } \\
\text { operation. }\end{array}$ & $\begin{array}{l}\text { Field } \\
\text { collection of } \\
\text { vegetation } \\
\text { samples. }\end{array}$ & $\begin{array}{l}\text { Regulation and } \\
\text { enforcement: Enforce } \\
\text { Idaho fluorine air- } \\
\text { quality standards } \\
\text { (includes standards } \\
\text { for concentration } \\
\text { in vegetation). } \\
\text { Planning: Avoid } \\
\text { contamination of } \\
\text { rangeland and agri- } \\
\text { cultural lands by } \\
\text { site planning. }\end{array}$ \\
\hline $\begin{array}{l}\text { Surface-water } \\
\text { quality : sediment } \\
\text { yield increase, } \\
\text { chemical contami- } \\
\text { nants, biological } \\
\text { health } \\
\text { Sediment yield: } \\
\text { flow, turbidity, } \\
\text { nonfilterable } \\
\text { solids, } \\
\text { conductivity. } \\
\text { Chemical con- } \\
\text { taminants: } \\
\text { Temperature, } \\
\text { dissolved oxygen, } \\
\text { total potassium, } \\
\mathrm{NO}_{3} \text {, pH, PO, }\end{array}$ & $\begin{array}{l}\text { Mining and } \\
\text { processing: } \\
\text { All phases. }\end{array}$ & $\begin{array}{l}\text { U.S. Geological } \\
\text { Survey; U.S. } \\
\text { Environmental } \\
\text { Protection } \\
\text { Agency; U.S. } \\
\text { Forest Service; } \\
\text { U.S. Fish and } \\
\text { Wildlife Service; } \\
\text { Idaho Depart- } \\
\text { ment of Health } \\
\text { and Welfare; } \\
\text { Southeast Idaho } \\
\text { Council of } \\
\text { Governments. }\end{array}$ & $\begin{array}{l}\text { Downstream of } \\
\text { minesites and } \\
\text { processing } \\
\text { plants; in } \\
\text { reservoirs for } \\
\text { eutrophication } \\
\text { levels. }\end{array}$ & $\begin{array}{l}\text { Sediment } \\
\text { yield: } 2-3 \\
\text { times during } \\
\text { runoff and } \\
\text { bimonthly rest } \\
\text { of year. } \\
\text { Chemical } \\
\text { contaminants: } \\
\text { Once during } \\
\text { runoff and } \\
\text { bimonthly for } \\
\text { all chemicals } \\
\text { except for heavy } \\
\text { metals to be } \\
\text { collected during } \\
\text { high and low } \\
\text { flow only. }\end{array}$ & $\begin{array}{l}\quad \text { Field } \\
\text { samples } \\
\text { using } \\
\text { standard } \\
\text { methods and } \\
\text { procedures. }\end{array}$ & $\begin{array}{l}\text { Regulation and } \\
\text { enforcement: } \\
\text { Enforce State and } \\
\text { Federal water- } \\
\text { quality standards, } \\
\text { Fish and Wildlife } \\
\text { Coordination Act, } \\
\text { and other } \\
\text { regulations for } \\
\text { protection of } \\
\text { aquatic resources. } \\
\text { Decisionmaking: } \\
\text { Determine success } \\
\text { of management } \\
\text { policies and } \\
\text { mitigating } \\
\text { measures; identify }\end{array}$ \\
\hline
\end{tabular}


TABLE 7.-Monitoring data needs-Continued

\begin{tabular}{|c|c|c|c|c|c|c|c|}
\hline $\begin{array}{l}\text { Impacts and } \\
\text { impact indicator }(\mathrm{s})\end{array}$ & $\begin{array}{l}\text { Timing of } \\
\text { impact }\end{array}$ & $\begin{array}{l}\text { Agency responsible } \\
\text { for collection }\end{array}$ & $\begin{array}{l}\text { Location or site } \\
\text { where data are } \\
\text { to be measured }\end{array}$ & $\begin{array}{l}\text { Collection } \\
\text { frequency }\end{array}$ & $\begin{array}{l}\text { Collection } \\
\text { method }\end{array}$ & Use of data & Remarks \\
\hline $\begin{array}{l}\text { Chemical con- } \\
\text { taminants-Continue } \\
\text { chemical oxygen } \\
\text { demand; } \\
\text { Hardness: } \mathrm{Mg}, \mathrm{SO}_{4} \text {, } \\
\text { F, alkalinity, } \mathrm{K} \text {, total } \\
\text { phosphate, } \mathrm{Fe} \text {, } \\
\mathrm{Mn}, \mathrm{As}, \mathrm{Cd}, \mathrm{Cr} \text {, } \\
\mathrm{Se}, \mathrm{V}, \mathrm{U}, \mathrm{Z}, \mathrm{Cu} \text {. }\end{array}$ & & & & & & $\begin{array}{l}\text { Chemical con- } \\
\text { taminants-continued: } \\
\text { need for addi- } \\
\text { tional water- } \\
\text { quality controls } \\
\text { and techniques. } \\
\text { Develop appro- } \\
\text { priate water- } \\
\text { quality standards. }\end{array}$ & \\
\hline $\begin{array}{l}\text { Biological } \\
\text { health: coliform, } \\
\text { benthos species } \\
\text { diversity, peri- } \\
\text { phyton, eutrophica- } \\
\text { tion level (plankton } \\
\mathrm{PO}_{4}, \mathrm{NO}_{3} \text {, total Kjel- } \\
\text { dahl nitrogen, } \\
\text { chemical oxygen } \\
\text { demand, dissolved } \\
\text { oxygen), pH, conduc- } \\
\text { tivity, } \mathrm{SO}_{4}, \mathrm{~F} \text {, alkalin } \\
\text { ity, total phosphate. }\end{array}$ & & & & $\begin{array}{l}\quad \text { Biological } \\
\text { health: } \\
\text { Coliform and } \\
\text { benthos } \\
\text { bimonthly, } \\
\text { periphyton } \\
\text { quarterly, and } \\
\text { eutrophica- } \\
\text { tion level } \\
\text { twice in } \\
\text { summer. }\end{array}$ & & $\begin{array}{l}\text { Planning: Site } \\
\text { planning of future } \\
\text { land uses and } \\
\text { determination of } \\
\text { allowable dis- } \\
\text { charge levels. } \\
\text { State } 208 \text { water- } \\
\text { quality planning. }\end{array}$ & 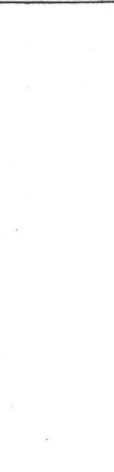 \\
\hline $\begin{array}{l}\text { Water use by } \\
\text { processing plants; } \\
\text { municipal water } \\
\text { use induced by } \\
\text { phosphate } \\
\text { development } \\
\text { Acre-feet/year } \\
\text { of processing } \\
\text { plant use. } \\
\text { Annual popula- } \\
\text { tion increase from } \\
\text { phosphate } \\
\text { development } \\
\text { multiplied by } \\
\text { average per capita } \\
\text { water consumption. }\end{array}$ & $\begin{array}{l}\text { Processing: } \\
\text { Construction } \\
\text { and operation } \\
\text { phases. } \\
\quad \text { Mining: } \\
\text { Construction } \\
\text { and operation } \\
\text { phases. }\end{array}$ & $\begin{array}{l}\text { Idaho Depart- } \\
\text { ment of Water } \\
\text { Resources. }\end{array}$ & $\begin{array}{l}\text { Processing } \\
\text { plant use: } \\
\text { Processing } \\
\text { plants. } \\
\text { Municipal } \\
\text { water use: } \\
\text { Areawide. }\end{array}$ & Annually. & $\begin{array}{l}\quad \text { Water use } \\
\text { by processing } \\
\text { plants: } \\
\text { Watermeter. } \\
\quad \text { Municipal } \\
\text { water use: } \\
\text { Statistical } \\
\text { record of } \\
\text { population } \\
\text { and per capita } \\
\text { water } \\
\text { consumption. }\end{array}$ & $\begin{array}{l}\text { Regulation and } \\
\text { enforcement: } \\
\text { Enforcement of } \\
\text { State water rights } \\
\text { regulations. } \\
\text { Decisionmaking: } \\
\text { Allocation of } \\
\text { water rights. } \\
\text { Planning: Allo- } \\
\text { cation of future } \\
\text { water rights, } \\
\text { planning munici- } \\
\text { pal and industrial } \\
\text { growth to limit } \\
\text { water demand to } \\
\text { available supply. }\end{array}$ & \\
\hline
\end{tabular}


TABLE 7.-Monitoring data needs-Continued

\begin{tabular}{|c|c|c|c|c|c|c|c|}
\hline $\begin{array}{l}\text { Impacts and } \\
\text { impact indicator }(\mathrm{s})\end{array}$ & $\begin{array}{l}\text { Timing of } \\
\text { impact }\end{array}$ & $\begin{array}{l}\text { Agency responsible } \\
\text { for collection }\end{array}$ & $\begin{array}{l}\text { Location or site } \\
\text { where data are } \\
\text { to be measured }\end{array}$ & $\begin{array}{l}\text { Collection } \\
\text { frequency }\end{array}$ & $\begin{array}{l}\text { Collection } \\
\text { method }\end{array}$ & Use of data & Remarks \\
\hline $\begin{array}{l}\text { Air quality: } \\
\text { fugitive dust and } \\
\text { chemical } \\
\text { contamination. } \\
\text { Total suspended } \\
\text { particulate matter } \\
\text { in micrograms } \\
\text { per cubic meter. } \\
\text { Ambient fluoride } \\
\text { in parts per } \\
\text { million. } \\
\text { Sulfur dioxide } \\
\text { in parts per } \\
\text { million. }\end{array}$ & $\begin{array}{l}\text { Mining: } \\
\text { Construction } \\
\text { and operation } \\
\text { phases. } \\
\text { Processing: } \\
\text { Production. }\end{array}$ & $\begin{array}{l}\text { Minesites: } \\
\text { U.S. Geological } \\
\text { Survey (requires } \\
\text { industry to } \\
\text { collect the data). } \\
\text { Processing } \\
\text { plants: Idaho } \\
\text { Department of } \\
\text { Health and } \\
\text { Welfare Division } \\
\text { of the Environ- } \\
\text { ment (data } \\
\text { furnished to } \\
\text { U.S. Environ- } \\
\text { mental Protec- } \\
\text { tion Agency. }\end{array}$ & $\begin{array}{l}\text { Total sus- } \\
\text { pended particu- } \\
\text { late matter: } \\
\text { Minesite process- } \\
\text { ing plants, } \\
\text { transportation } \\
\text { networks. } \\
\text { Ambient fluo- } \\
\text { ride: Processing } \\
\text { plants. } \\
\text { Sulfur dioxide: } \\
\text { Processing } \\
\text { plants. }\end{array}$ & $\begin{array}{l}\text { Total } \\
\text { suspended } \\
\text { particulate } \\
\text { matter: } \\
\text { Continuous- } \\
\text { hourly, re- } \\
\text { corded as } \\
\text { average 24- } \\
\text { hour concen- } \\
\text { tration. } \\
\quad \text { Ambient } \\
\text { fluoride and } \\
\text { sulfur dioxide: } \\
\text { Continuous- } \\
\text { hourly, re- } \\
\text { corded as } \\
\text { average 24- } \\
\text { hour concen- } \\
\text { tration and } \\
\text { as average } \\
\text { 3-hour con- } \\
\text { centration. }\end{array}$ & $\begin{array}{l}\text { Continuous } \\
\text { instrumenta- } \\
\text { tion. }\end{array}$ & $\begin{array}{l}\text { Regulation and } \\
\text { enforcement: } \\
\text { Enforce existing } \\
\text { air-quality } \\
\text { regulations. } \\
\text { Decisiommaking: } \\
\text { Determine attain- } \\
\text { able standards, } \\
\text { develop new } \\
\text { regulations; } \\
\text { determine level } \\
\text { of plant pro- } \\
\text { duction that is } \\
\text { feasible within } \\
\text { standards. } \\
\text { Planning: } \\
\text { Minimize pollu- } \\
\text { tion levels by } \\
\text { site planning of } \\
\text { future processing } \\
\text { plants; evaluate } \\
\text { potential new } \\
\text { source con- } \\
\text { struction. }\end{array}$ & . \\
\hline $\begin{array}{l}\text { Radiation released } \\
\text { in air and water } \\
\text { Air: Gross } \\
\text { alpha, } \mathrm{Ra}^{226} \text {, } \\
\mathrm{Th}^{230}, \mathrm{Po}^{210} \text {. } \\
\text { Water: Gross } \\
\text { alpha, gross } \\
\text { beta, } \mathrm{Ra}^{226} \text {. }\end{array}$ & $\begin{array}{l}\text { Processing: } \\
\text { Operation } \\
\text { phase. }\end{array}$ & $\begin{array}{l}\text { Idaho Depart- } \\
\text { ment of Health } \\
\text { and Welfare. }\end{array}$ & $\begin{array}{l}\text { Air: Upwind } \\
\text { and downwind } \\
\text { of processing } \\
\text { plants within } \\
\text { 1/2-mile radius; } \\
\text { within process- } \\
\text { ing plant. } \\
\text { Water: Sub- } \\
\text { surface water } \\
\text { under or near } \\
\text { processing plants } \\
\text { that could be } \\
\text { affected by } \\
\text { stockpiles or } \\
\text { waste ponds. }\end{array}$ & $\begin{array}{l}\text { Quarterly } \\
\text { initially, } \\
\text { revised as } \\
\text { needed. }\end{array}$ & $\begin{array}{l}\text { Air: ? } \\
\text { Water: } \\
\text { TLD } \\
\text { dosimeter. }\end{array}$ & $\begin{array}{l}\text { Regulation and } \\
\text { enforcement: } \\
\text { Enforce Idaho } \\
\text { Radiation Con- } \\
\text { trol Regulations. } \\
\text { Decisionmaking: } \\
\text { Make adjustments } \\
\text { in radiation } \\
\text { controls as needed. }\end{array}$ & \\
\hline
\end{tabular}


TABLE 7.-Monitoring data needs-Continued

\begin{tabular}{|c|c|c|c|c|c|c|c|}
\hline $\begin{array}{c}\text { Impacts and } \\
\text { impact indicator }(\mathrm{s})\end{array}$ & $\begin{array}{l}\text { Timing of } \\
\text { impact }\end{array}$ & $\begin{array}{l}\text { Agency responsible } \\
\text { for collection }\end{array}$ & $\begin{array}{l}\text { Location or site } \\
\text { where data are } \\
\text { to be measured }\end{array}$ & $\begin{array}{l}\text { Collection } \\
\text { frequency }\end{array}$ & $\begin{array}{l}\text { Collection } \\
\text { method }\end{array}$ & Use of data & Remarks \\
\hline $\begin{array}{l}\text { Wildlife: degrada- } \\
\text { tion or loss of } \\
\text { endangered species } \\
\text { habitat; roadkill } \\
\text { and obstruction } \\
\text { of migration } \\
\text { routes; loss of } \\
\text { resident species' } \\
\text { habitat } \\
\text { Carrying } \\
\text { capacity and } \\
\text { acreage of } \\
\text { endangered species' } \\
\text { wildlife habitat. } \\
\text { Roadkills and } \\
\text { number of dead } \\
\text { animals along } \\
\text { transportation } \\
\text { networks and at } \\
\text { bottom of high- } \\
\text { walls, number of } \\
\text { animals in } \\
\text { traditional winter } \\
\text { range areas. } \\
\text { Acreage of wild- } \\
\text { life habitat } \\
\text { replaced by } \\
\text { vegetation } \\
\text { categories: } \\
\text { Conifers, hard- } \\
\text { wood, conifer/ } \\
\text { hardwood mix, } \\
\text { woodland, riparian, } \\
\text { sagebrush, tall } \\
\text { shrub, snowbank } \\
\text { shrub, meadow, } \\
\text { barren, strip } \\
\text { mine, seeded } \\
\text { pasture, cropland, } \\
\text { and herbaceous. }\end{array}$ & $\begin{array}{l}\text { All phases } \\
\text { of mining } \\
\text { and } \\
\text { processing. }\end{array}$ & $\begin{array}{l}\text { U.S. Fish and } \\
\text { Wildlife Service; } \\
\text { Bureau of Land } \\
\text { Management; } \\
\text { U.S. Forest } \\
\text { Service; Idaho } \\
\text { Department of } \\
\text { Fish and Game. }\end{array}$ & $\begin{array}{l}\text { Study area, } \\
\text { endangered } \\
\text { species areas. }\end{array}$ & Annually. & $\begin{array}{l}\text { Carrying } \\
\text { capacity: } \\
\text { Field } \\
\text { examination. } \\
\quad \text { Habitat } \\
\text { acreage: } \\
\text { Remote } \\
\text { sensing at } \\
\text { scale of } \\
1: 24,000 \text { with } \\
\text { field verifica- } \\
\text { tion checks. } \\
\quad \text { Roadkills, } \\
\text { etc.: Statisti- } \\
\text { cal records } \\
\text { of dead } \\
\text { animals found. }\end{array}$ & $\begin{array}{l}\text { Regulation and } \\
\text { enforcement: } \\
\text { Enforce Endan- } \\
\text { gered Species Act. } \\
\text { Decisionmaking: } \\
\text { Identify need for } \\
\text { improvement in } \\
\text { habitat quality } \\
\text { and acreage. } \\
\text { Determination } \\
\text { of appropriate } \\
\text { number of } \\
\text { hunting permits. } \\
\text { Development of } \\
\text { management } \\
\text { techniques. } \\
\text { Structures for } \\
\text { minimizing trans- } \\
\text { portation and } \\
\text { highwall-related } \\
\text { accidents and } \\
\text { for facilitating } \\
\text { seasonal } \\
\text { migration. }\end{array}$ & \\
\hline
\end{tabular}


TABLE 7.-Monitoring data needs-Continued

\begin{tabular}{|c|c|c|c|c|c|c|}
\hline $\begin{array}{c}\text { Impacts and } \\
\text { impact indicator(s) }\end{array}$ & $\begin{array}{l}\text { Agency responsible } \\
\text { for collection }\end{array}$ & $\begin{array}{l}\text { Location or site } \\
\text { where data are } \\
\text { to be measured }\end{array}$ & $\begin{array}{l}\text { Collection } \\
\text { frequency }\end{array}$ & $\begin{array}{c}\text { Collection } \\
\text { method }\end{array}$ & Use of data & Remarks \\
\hline \multicolumn{7}{|l|}{$\begin{array}{l}\text { Aquatic life } \\
\text { quality } \\
\text { See surface- } \\
\text { water quality: } \\
\text { biological health. }\end{array}$} \\
\hline $\begin{array}{l}\text { Land use/land } \\
\text { cover change mining and } \\
\text { Location and processing. } \\
\text { acreage of exist- } \\
\text { ing land use/ } \\
\text { land cover. } \\
\text { Location and } \\
\text { acreage of change. } \\
\text { Classification by } \\
\text { the following } \\
\text { categories: } \\
\text { Residential; commercial } \\
\text { and services; indus- } \\
\text { trial, transporta- } \\
\text { tion, communica- } \\
\text { tions, and utilities; } \\
\text { other urban or built- } \\
\text { up land; cropland } \\
\text { and pasture; other } \\
\text { agricultural land; } \\
\text { herbaceous range- } \\
\text { land; shrub and } \\
\text { brush rangeland; } \\
\text { mixed rangeland; } \\
\text { deciduous forest } \\
\text { land; evergreen } \\
\text { forest land; streams } \\
\text { and canals; lakes; } \\
\text { reservoirs; for- } \\
\text { ested wetland; } \\
\text { strip mines, } \\
\text { quarries, and } \\
\text { gravel pits; } \\
\text { transitional areas. }\end{array}$ & $\begin{array}{l}\text { Southeast } \\
\text { Idaho Council of } \\
\text { Governments; } \\
\text { Idaho Division } \\
\text { of Budget, } \\
\text { Policy Planning } \\
\text { and Coordina- } \\
\text { tion; U.S. } \\
\text { Forest Service; } \\
\text { U.S. Bureau of } \\
\text { Land Manage- } \\
\text { ment. }\end{array}$ & $\begin{array}{l}\text { Study areawide } \\
\text { for all cate- } \\
\text { gories. } \\
\text { Selected change } \\
\text { areas for sub- } \\
\text { categories. }\end{array}$ & Annually. & $\begin{array}{l}\text { Remote } \\
\text { sensing at a } \\
\text { scale of } \\
1: 24,000 \text { with } \\
\text { field verifica- } \\
\text { tion checks. }\end{array}$ & $\begin{array}{l}\text { Decisionmaking: } \\
\text { Determine need } \\
\text { for zoning changes, } \\
\text { develop new re- } \\
\text { source manage- } \\
\text { ment policies as } \\
\text { needed, realloca- } \\
\text { tion of water } \\
\text { rights, location of } \\
\text { urban develop- } \\
\text { ment, development } \\
\text { of nonpoint source } \\
\text { pollution control } \\
\text { strategies. } \\
\text { Planning: Plan } \\
\text { development of } \\
\text { local infra- } \\
\text { structures to } \\
\text { meet human } \\
\text { settlement pat- } \\
\text { terns; plan } \\
\text { development of } \\
\text { parks and recrea- } \\
\text { tion; plan } \\
\text { multiple-use } \\
\text { development on } \\
\text { Federal lands. }\end{array}$ & * \\
\hline
\end{tabular}


TABLE 7.-Monitoring data needs-Continued

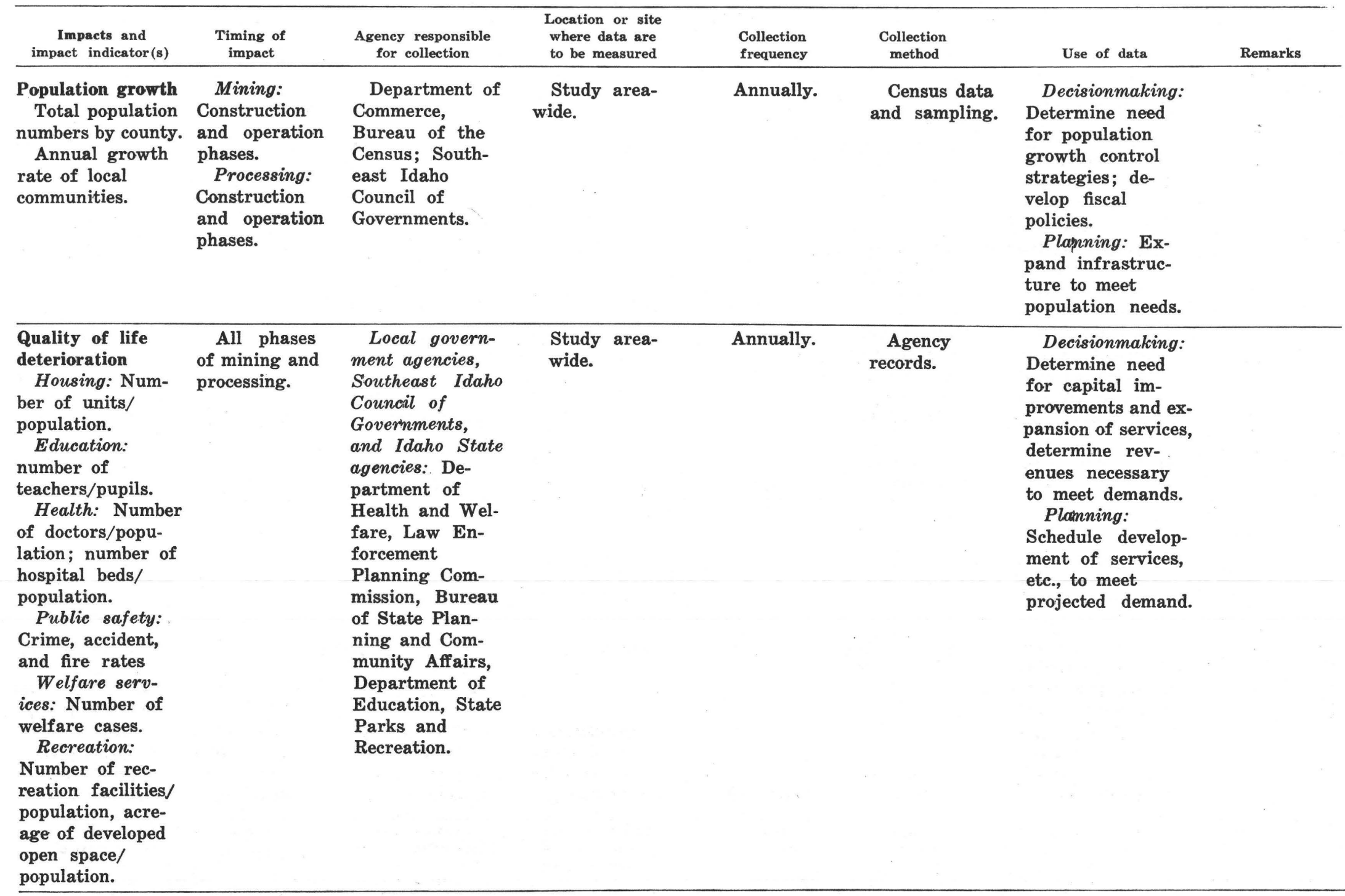


TABLE 7.-Monitoring data needs-Continued

\begin{tabular}{|c|c|c|c|c|c|c|c|}
\hline $\begin{array}{c}\text { Impacts and } \\
\text { impact indicator }(\mathrm{s})\end{array}$ & $\begin{array}{l}\text { Timing of } \\
\text { impact }\end{array}$ & $\begin{array}{l}\text { Agency responsible } \\
\text { for collection }\end{array}$ & $\begin{array}{l}\text { Location or site } \\
\text { where data are } \\
\text { to be measured }\end{array}$ & $\begin{array}{l}\text { Collection } \\
\text { frequency }\end{array}$ & $\begin{array}{l}\text { Collection } \\
\text { method }\end{array}$ & Use of data & Remarks \\
\hline $\begin{array}{l}\text { Fiscal government } \\
\text { costs/revenues } \\
\text { Total fiscal gov- } \\
\text { ernment costs. } \\
\text { Total revenues } \\
\text { received. }\end{array}$ & $\begin{array}{l}\text { All phases } \\
\text { of mining } \\
\text { and } \\
\text { processing. }\end{array}$ & $\begin{array}{l}\text { Local govern- } \\
\text { ments; Southeast } \\
\text { Idaho Council } \\
\text { of Governments. }\end{array}$ & $\begin{array}{l}\text { Communities } \\
\text { experiencing } \\
\text { rapid popula- } \\
\text { tion growth. }\end{array}$ & Annually. & $\begin{array}{l}\text { Fiscal } \\
\text { records. }\end{array}$ & $\begin{array}{l}\text { Decisionmaking: } \\
\text { Balance costs and } \\
\text { revenues by } \\
\text { adjusting ex- } \\
\text { penditures to tax } \\
\text { rates and bonding } \\
\text { capacity and vice } \\
\text { versa. } \\
\text { Planning: Inte- } \\
\text { grate planning of } \\
\text { infrastructure } \\
\text { development and } \\
\text { revenue acqui- } \\
\text { sition. }\end{array}$ & \\
\hline $\begin{array}{l}\text { Employment } \\
\text { level changes } \\
\text { Number of } \\
\text { workers em- } \\
\text { ployed by mining } \\
\text { and processing } \\
\text { companies. } \\
\text { Unemployment } \\
\text { rate. }\end{array}$ & $\begin{array}{l}\text { All phases } \\
\text { of mining } \\
\text { and } \\
\text { processing. }\end{array}$ & $\begin{array}{l}\text { Idaho Depart- } \\
\text { ment of Em- } \\
\text { ployment; U.S. } \\
\text { Department of } \\
\text { Labor. }\end{array}$ & $\begin{array}{l}\text { Study area- } \\
\text { wide. }\end{array}$ & Monthly. & $\begin{array}{l}\text { Company } \\
\text { records of } \\
\text { number of } \\
\text { employees on } \\
\text { payroll (must } \\
\text { obtain from } \\
\text { industry with } \\
\text { permission to } \\
\text { make public). } \\
\text { Unemploy- } \\
\text { ment records } \\
\text { by county. }\end{array}$ & $\begin{array}{l}\text { Decisionmaking: } \\
\text { Alert agencies to } \\
\text { boom-bust condi- } \\
\text { tions and need for } \\
\text { changes in fiscal } \\
\text { policies, expan- } \\
\text { sion or contrac- } \\
\text { tion of service } \\
\text { levels; need for } \\
\text { soliciting addi- } \\
\text { tional job } \\
\text { opportunities in } \\
\text { community, ob- } \\
\text { taining funding } \\
\text { for unemployment } \\
\text { compensation. } \\
\text { Planning: Plan } \\
\text { for adapting to } \\
\text { sudden shifts in } \\
\text { number of jobs } \\
\text { and unemployment } \\
\text { level. }\end{array}$ & \\
\hline
\end{tabular}


TABLE 7.-Monitoring data needs-Continued

\begin{tabular}{|c|c|c|c|c|c|c|c|}
\hline $\begin{array}{c}\text { Impacts and } \\
\text { impact indicator }(\mathrm{s})\end{array}$ & $\begin{array}{l}\text { Timing of } \\
\text { impact }\end{array}$ & $\begin{array}{l}\text { Agency responsible } \\
\text { for collection }\end{array}$ & $\begin{array}{l}\text { Location or site } \\
\text { where data are } \\
\text { to be measured }\end{array}$ & $\begin{array}{l}\text { Collection } \\
\text { frequency }\end{array}$ & $\begin{array}{l}\text { Collection } \\
\text { method }\end{array}$ & Use of data & Remarks \\
\hline $\begin{array}{l}\text { Increased traffic } \\
\text { volume and } \\
\text { expansion of } \\
\text { transportation } \\
\text { networks; } \\
\text { demand for } \\
\text { utilities and } \\
\text { expansion of } \\
\text { utility networks } \\
\text { Acreage of } \\
\text { transportation and } \\
\text { utility networks- } \\
\text { See Land use/land } \\
\text { cover change. } \\
\text { Traffic volume } \\
\text { counts on network } \\
\text { serving minesites } \\
\text { and processing } \\
\text { plants. } \\
\text { Utility demand }\end{array}$ & $\begin{array}{l}\text { Mining: } \\
\text { Construction } \\
\text { and operation } \\
\text { phases. } \\
\text { Processing: } \\
\text { Construction } \\
\text { and operation } \\
\text { phases. }\end{array}$ & $\begin{array}{l}\text { Idaho Trans- } \\
\text { portation De- } \\
\text { partment, Idaho } \\
\text { Public Utilities } \\
\text { Commission. }\end{array}$ & $\begin{array}{l}\quad \text { Study area- } \\
\text { wide; traffic } \\
\text { volume counts } \\
\text { limited to net- } \\
\text { works serving } \\
\text { minesites and } \\
\text { processing } \\
\text { plants. }\end{array}$ & Annually. & $\begin{array}{l}\text { Traffic } \\
\text { volume } \\
\text { counts. } \\
\text { Utility } \\
\text { records. }\end{array}$ & $\begin{array}{l}\text { Decisionmaking: } \\
\text { Determine when } \\
\text { traffic volumes } \\
\text { could support } \\
\text { mass transit, } \\
\text { establish addi- } \\
\text { tional traffic con- } \\
\text { trol measures } \\
\text { as needed. } \\
\text { Planning: Ex- } \\
\text { pansion and } \\
\text { upgrading of } \\
\text { transportation and } \\
\text { utility networks. }\end{array}$ & \\
\hline levels. & & . & & & & & \\
\hline $\begin{array}{l}\text { Increased energy } \\
\text { demand } \\
\text { Kilowatt hours } \\
\text { of electricity } \\
\text { consumed. } \\
\text { Tons of coal } \\
\text { consumed. } \\
\text { Cubic feet per } \\
\text { minute of natural } \\
\text { gas consumed. } \\
\text { Gallons of fuel. }\end{array}$ & $\begin{array}{l}\text { Mining: } \\
\text { Construction } \\
\text { and operation } \\
\text { phases. } \\
\text { Processing: } \\
\text { Construction } \\
\text { and operation } \\
\text { phases. }\end{array}$ & $\begin{array}{l}\text { Idaho Public } \\
\text { Utility } \\
\text { Commission. }\end{array}$ & $\begin{array}{l}\text { Processing } \\
\text { plants: Elec- } \\
\text { tricity, coal, } \\
\text { natural gas. } \\
\quad \text { Minesites and } \\
\text { processing plants: } \\
\text { Fuel consumed } \\
\text { transporting } \\
\text { people and } \\
\text { materials. }\end{array}$ & Annually. & \begin{tabular}{l}
\multicolumn{2}{c}{ Industry } \\
records (ob- \\
tain permis- \\
sion for \\
public \\
disclosure).
\end{tabular} & $\begin{array}{l}\text { Decisionmaking: } \\
\text { Determine need } \\
\text { for expansion } \\
\text { of energy supply. } \\
\text { Planning: Plan } \\
\text { expansion of } \\
\text { energy supply, } \\
\text { developing strate- } \\
\text { gies for conserva- } \\
\text { tion of available } \\
\text { energy. }\end{array}$ & \\
\hline
\end{tabular}


TABLE 7.-Monitoring data needs-Continued

\begin{tabular}{|c|c|c|c|c|c|c|c|}
\hline $\begin{array}{c}\text { Impacts and } \\
\text { impact indicator }(\mathrm{s})\end{array}$ & $\begin{array}{c}\text { Timing of } \\
\text { impact }\end{array}$ & $\begin{array}{l}\text { Agency responsible } \\
\text { for collection }\end{array}$ & $\begin{array}{l}\text { Location or site } \\
\text { where data are } \\
\text { to be measured }\end{array}$ & $\begin{array}{l}\text { Collection } \\
\text { frequency }\end{array}$ & $\begin{array}{c}\text { Collection } \\
\text { method }\end{array}$ & Use of data & Remarks \\
\hline $\begin{array}{l}\text { Archeologic site } \\
\text { destruction } \\
\text { Number and } \\
\text { location of } \\
\text { archeologic sites. } \\
\text { Number of } \\
\text { archeologic sites } \\
\text { destroyed. }\end{array}$ & $\begin{array}{l}\text { Mining: } \\
\text { Construction } \\
\text { and operation } \\
\text { phases. } \\
\text { Processing: } \\
\text { Construction } \\
\text { phase. }\end{array}$ & $\begin{array}{l}\text { U.S. Geological } \\
\text { Survey, U.S. } \\
\text { Forest Service, } \\
\text { U.S. Bureau of } \\
\text { Land Manage- } \\
\text { ment, Idaho } \\
\text { State Historical } \\
\text { Society. }\end{array}$ & $\begin{array}{l}\text { Minesites, rail- } \\
\text { roads and haul } \\
\text { roads, processing } \\
\text { plants. }\end{array}$ & Annually. & $\begin{array}{c}\text { Field } \\
\text { reports. }\end{array}$ & $\begin{array}{l}\text { Regulation and } \\
\text { enforcement: } \\
\text { Enforce con- } \\
\text { gressional acts } \\
\text { and executive } \\
\text { orders dealing } \\
\text { with preservation } \\
\text { of historic and } \\
\text { archeologic sites } \\
\text { and Idaho State } \\
\text { Antiquities Act. } \\
\text { Decisionmaking: } \\
\text { Establish } \\
\text { protection } \\
\text { measures. } \\
\text { Planning: Plan } \\
\text { for compatible } \\
\text { land-use develop- } \\
\text { ment adjacent to } \\
\text { valuable archeo- } \\
\text { logic sites. }\end{array}$ & \\
\hline
\end{tabular}




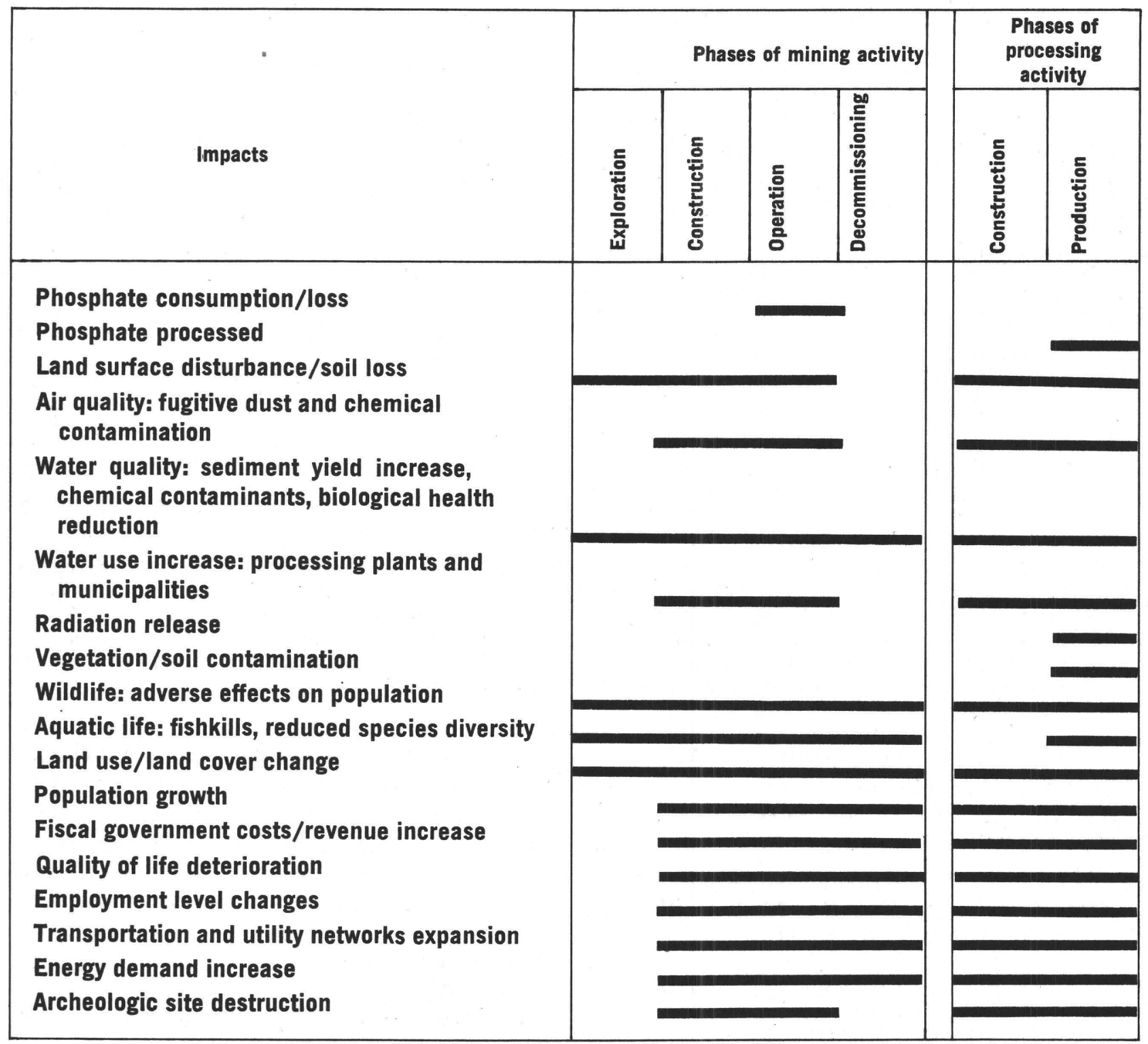

FIGURE 1.-Activity/impact schedule: Phases of mining and processing activities during which impacts are most likely to occur. 


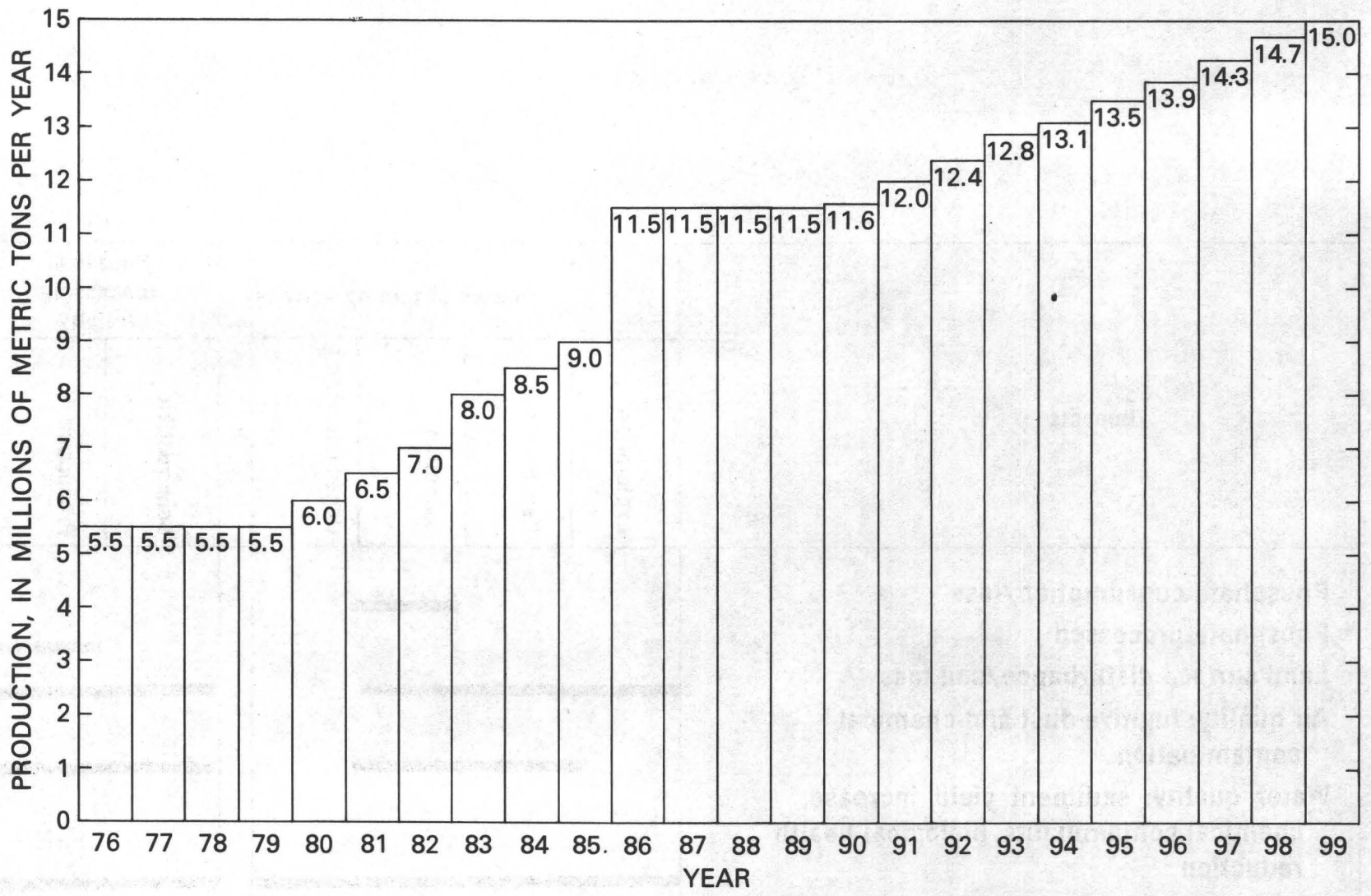

Figure 2.-Assumed total production of phosphate in southeastern Idaho through 1999. [Data are for the following mines: Diamond Creek, Swan Lake Gulch, South Maybe Canyon, Champ, Mountain Fuel, ParisBloomington, Dry Valley, Husky No. 1, Henry, North Henry Continuation, Trail Creek, Caldwell Canyon, Blackfoot Bridge, Conda, North Trail, Middle Sulfur, Wooley Valley, Wooley Valley No. 3, Rasmussen Ridge. Data are adapted from table 1-1 from "Final Environmental Impact Statement; Development of Phosphate Resources in Southeastern Idaho" (U.S. Geological Survey, 1977)].

of individual mines to their geographic location. This schedule can be used to indicate when the collective impact of mines in an area is likely to exceed critical impact levels. For example, the collective impact of mines that are contributing sediment to the same drainage basin area can be determined.

\section{STATUS OF MONITORING PROGRAMS}

Many agencies are presently initiating their own or interagency monitoring programs. Workshop participants who worked on watermonitoring data needs have established a work committee to develop a cooperative waterquality monitoring program, and several agencies are proceeding to adapt existing datacollection efforts to meet monitoring data needs.

No institutional mechanism has been designated thus far to coordinate a comprehensive monitoring system. Continuing agency support and the EIS recommendation that an inter- agency monitoring program be established to mitigate impacts may result in the creation of an appropriate institutional mechanism. Mechanisms that have potential for coordinating a comprehensive monitoring program include: the A-95 clearinghouses, the State plan review process, and an organization of severai intergovernmental work groups and committees.

\section{REFINEMENT OF MONITORING METHODOLOGY}

The workshop enabled the author to evaluate basic premises and a proposed procedure for developing monitoring systems. It resulted in an expanded methodology for development and operation of monitoring systems described on the following pages.

\section{MONITORING METHODOLOGY INTRODUCTION}

The purpose of this methodology is to assist agencies in developing and operating optimum, 
intergovernmental monitoring systems. Monitoring systems have typically been very detailed, intensive data collection efforts. The reams of data produced then require considerable time for analysis. Data collection and analysis are too expensive and time consuming to be wasted on nonspecific and nonessential information. This methodology helps design optimum monitoring systems by requiring that all data needs be justified on the basis of value for sound decisionmaking, planning, and regulation and enforcement. The methodology also limits monitoring to selected major impacts and to impacts that agencies have authority and/or responsibility to affect significantly.

\section{FOGUS OF MONITORING METHODOLOGY}

This methodology is responsive to the monitoring objectives of field level and national planning and decisionmaking. The primary focus of this methodology is on development of a monitoring system that improves agencies' capabilities to make informed and effective responses to the impacts resulting from major Federal actions; thus, it meets the needs of those agencies directly responsible at a field level for substantially minimizing impacts. These agencies need data that will indicate in a timely fashion when agency intervention is necessary to minimize an impact and that will provide feedback on the success of mitigating measures.

A secondary focus is on the development of monitoring systems that document: (1) the type, magnitude, timing, duration, and location of impacts ; and (2) the conditions, restrictions, and mitigating measures that are successful in controlling impacts. Monitoring data will help agencies at the national planning and decisionmaking level to determine what actions shall take place and under what conditions, because these data contribute to more accurate prediction of the impacts that may result from similar projects and of the conditions that will be effective in controlling impacts. The monitoring data for this level of concern can be most efficiently provided from a field-level monitoring system by simply ensuring that summary documentation of these data is transmitted annually and is accessible when needed.

\section{METHOD OF DESGRIPTION}

The methodology has been divided into two phases ; Phase I. Development of a monitoring system, and Phase II. Implementation and operation of a monitoring system. Each phase is described by a flow chart and by a table that provides additional explanation. Each work element of the flow chart is numbered; the numbers refer to numbered descriptions on the table. Each work element is described by its objective, the tasks that accomplish it, and the end result or products.

The methodology is designed to be flexible. Feedback loops on the flow chart indicate when iterations of some work elements may be necessary or desirable. For example, after a feasibility analysis of a proposed monitoring system is conducted, monitoring objectives and the successive work elements may require redefinition in order to achieve a feasible proposal. Changing circumstances such as changes in the action being monitored or new knowledge gained from the operation of a monitoring system will probably require changes in the system. The methodology can be applied at any point to make revisions in the design or operation of these monitoring systems.

\section{PHASE I. DEVELOPMENT OF A MONITORING SYSTEM}

\section{CONSIDERATIONS FOR DEVELOPING A MONITORING SYSTEM}

The monitoring methodology presented incorporates several considerations.

1. The relationship of an action to the resulting impacts.-Both the action and the impacts are manifested by type, magnitude, timing (when and duration), and location. The multiple relationships between activities and impacts are often complex; understanding these relationships and correlating the activities with related impacts is the key to controlling impacts.

2. Agency authority, objectives.-Individual agencies have the authority and expertise to respond to some impacts. Monitoring objectives should be defined that assist agencies in obtaining information useful for controlling or mitigating impacts.

3. Data needs.-The particular data required to meet agencies' monitoring objectives can be 
described by type, frequency or timing of collection, location or site of measurement, and method of collection. In order to put these data in the context of the monitoring system, each data type should be identified by the impact it monitors and by the timing of that impact. It is also important to ensure that the various types of data collected can be interrelated. Standard data formats are necessary.

4. Feasibility of data collection.-Data-collection feasibility is affected by available funding, personnel, and the extent to which datacollection needs can be met within existing collection efforts. If data needs cannot be met within these constraints, then monitoring objectives and the corresponding data needs must be scaled downward. Feasibility constraints can be resolved in several ways: different types of data can be used to measure the impact, the number of measurements can be reduced by decreasing the frequency of collection or number of locations sampled, and the method of collection can be changed. However, any adjustments made in the data needs must adequately reflect monitoring objectives.

5. Need for flexibility.-The process of designing a monitoring system does not end when the system is implemented. Modification of the system is desirable as a better understanding is gained about how the environment is impacted, as circumstances change, and as agency authority to respond to impacts changes.

6. Need for interagency participation.-All agencies that have program responsibilities for controlling or responding to impact levels should participate in a common monitoring system. This sharing minimizes duplication of effort, ensures that the data collected meet the needs of the primary users, and that all information is available for solving problems. This last point is especially important because impacts are interrelated and, hence, should be addressed by multiagency expertise and authority.

\section{DESGRIPTION OF METHODOLOGY, PHASE I}

Phase I of the monitoring methodology, which developed from the aforementioned developmental considerations and from the workshop, is depicted by a flow chart (see plate 1 in pocket) and by explanatory table 8 .
PHASE II. IMPLEMENTATION AND OPERATION OF A MONITORING SYSTEM

CONSIDERATIONS FOR IMPLEMENTING AND OPERATING A MONITORING SYSTEM

1. Institutional structure.-The participating agencies must agree to some interagency structure and overall responsibility in order to coordinate funding, data collection, data analysis, information sharing, and responses to problems.

2. Data.-The data must be collected and analyzed. The magnitude, duration, and location of impacts can be correlated with the magnitude, duration, and location of activities. The significance of the data should be considered: what trends are developing, what is the rate of change, what critical impact levels have been reached, what impacts are related, are regulations and standards being met, and what is the degree of success for the mitigating measures.

3. Agency responses. - The collective authority of all participating agencies permits many choices for responding to unfavorable impacts. Agencies could cooperatively select the most effective response(s) from a total array of available agency powers and prerogatives. Some typical responses would be: planning for trends, contingency actions taken to alleviate emergency circumstances, enforcement of rules and regulations, changes in mitigating measures, and resource management decisions.

4. Communication. - Communication mechanisms ensure that all participants are informed of changes in activities and impacts and that agency responses to problems are coordinated. Communication includes documentation of impacts, data storage, and data retrieval. Data storage and retrieval could be a centralized function, but centralized data storage may result in user disinterest. The use of data-flow techniques instead may be more effective in maintaining a vital system.

\section{DESCRIPTION OF METHODOLOGY, PHASE II}

Phase II of the methodology which developed from these considerations is depicted by flow chart (see plate 2 in pocket) and by explanatory table 9. 
TABLE 8.-Explanation of flow chart of monitoring methodology: Phase I. Development of a Monitoring System

[See plate 1 in pocket]

Work element

1. Define action
Objectives

To determine type, scope, level, location, and timing of action(s) causing impacts.
Tasks necessary to

achieve objectives

1. Determine probable level of resource development, project market demands, formulate development schedule.

2. Describe action by its activity components. (Understanding of the specific activities is needed for impact prediction and for impact modification.)

3. Determine activities schedule. (Timing and duration of activities affects timing of impacts.)

4. Determine location of action.
To determine type, magnitude, timing, and location of impacts resulting from the action.
1. Prepare environmental impact statement. (EIS identifies impacts associated with each aspect of the environment and the activities causing the impact.) Predict impact magnitude, timing, and area to be affected.
Products or results

Development level schedule, see figure 2.
EIS description of impacts; see table 1 and figure 1.

Map delimiting boundaries of study area and identifying location of activities and probable impact areas.

$\begin{aligned} & \text { 3. Identify and define ma- } \\ & \text { jor impacts }\end{aligned}$
$\begin{gathered}\text { To identify impacts that } \\ \text { should be monitored. }\end{gathered}$ $\begin{gathered}\text { 1. Identify impacts to be moni- } \begin{array}{c}\text { List of impacts to be } \\ \text { tored on the basis of impact sig- monitored or activity/im- } \\ \text { nificance described in the EIS. }\end{array} \\ \text { pact matrix with impacts } \\ \text { requiring monitoring iden- } \\ \text { tified. See tables } 5 \text { and } 6 .\end{gathered}$


TABLE 8.-Explanation of flow chart of monitoring methodology: Phase I. Development of a Monitoring System-Continued

\begin{tabular}{ccccc}
\hline Work element & Objectives & Tasks necessary to & achieve objectives & Products or results \\
\hline $\begin{array}{l}\text { 4. Obtain participation of } \\
\text { agencies }\end{array}$ & $\begin{array}{c}\text { To obtain participation of } \\
\text { agencies in development of a } \\
\text { monitoring system. }\end{array}$ & $\begin{array}{c}\text { 1. Contact all agencies having } \\
\text { pertinent program responsibilities } \\
\text { in area to be impacted. }\end{array}$ & $\begin{array}{l}\text { Interagency participation } \\
\text { in the development of a } \\
\text { monitoring system. }\end{array}$
\end{tabular}

5. Identify agencies' au- $\begin{aligned} & \text { To identify agency poten- } \\ & \text { thority for controlling or miti- }\end{aligned}$
$\begin{array}{ll}\text { gating impacts } & \text { through responding to impacts } \\ \text { ing, planning, regulation, and } & \text { enforcement authority. }\end{array}$

1. Identify agencies' major areas of environmental concern. Determine for what aspects of the environment and for what type of impacts the agencies are responsible. (This focuses common areas of concern among agencies.)

2. Identify individual agency basis of authority to control impacts through decisionmaking, planning, regulation, and enforcement.

3. Identify additional agency authority necessary to integrate and coordinate the monitoring system.

6. Define monitoring ob- $\begin{gathered}\text { To define monitoring objec- } \\ \text { jectives }\end{gathered}$
tives.

1. Define monitoring objectives in terms of major potential impacts and in terms of agency authority. (The scope of the monitoring objectives determines the scope of the monitoring system. A general objective espoused by the author is that monitoring should be restricted to data collection that provides only that information necessary for carrying out impact reduction measures. Many of the major predicted impacts will be
List of agencies' areas of concern.

List of potential agency decisionmaking, planning, regulation, and enforcement responses to impacts. responses to impacts.

\author{
Statement of objectives \\ of monitoring system.
}


TABLE 8.-Explanation of flow chart of monitoring methodology: Phase I. Development of a Monitoring System-Continued

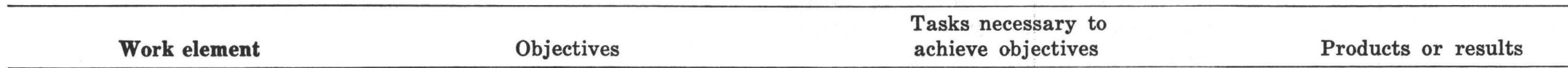

6. Define monitoring ob-

jectives-Continued

within the jurisdiction of a par-

ticular agency. However, agencies presently may have no authority for ameliorating some impacts. For such instances, agencies must determine whether their objectives will include monitoring some impacts that do not fall under the purview of their agency. Monitoring of such impacts may justify creation of appropriate control mechanisms in the future. However, agencies must not require a needlessly complex data collection effort.)

7. Determine data require-
ments

To determine data needs for achieving monitoring objectives. (Reiterations of this element may be necessary, based on revision of monitoring objectives, testing, and evaluation of data usefulness. See feedback loops on plate 1 , in pocket.)
1. Reevaluate impacts on the basis of monitoring objectives ; eliminate overlap in monitoring objectives and monitoring effort. (Some activities result in related environmental impacts. For example, ore extraction causes land surface disturbance, soil loss, and increased sediment yield. It may be sufficient to monitor only one of these impacts.

2. Select impact indicator. (This is the parameter that must be monitored to assess the magnitude of an impact. Several parameters may be indicative of a particular impact. Any impact indicator should be selected on the basis of
Descriptive list or table of monitoring requirements for each selected impact, including impact indicator, frequency and timing of collection, location of monitoring sites or areas, method of collection, and format. 


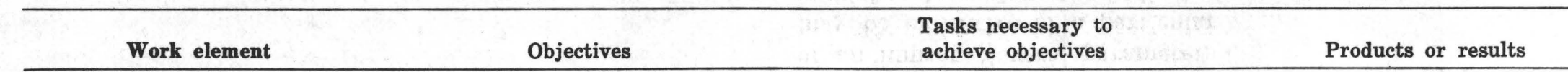

7. Determine data requirements-Continued its utility for decisionmaking, planning, regulation and enforcement. However, it may be necessary to use an alternative indicator if the necessary data are already being collected or the cost of monitoring the preferred parameter is high.)

3. Determine frequency and timing of data collection. (Frequency of data collection should be the minimum necessary for trend analysis, enforcement of regulations, and correlation of cause and effects. For some parameters the timing of data collection may be more important than the frequency level; for example, collection of water-quality data during a major runoff event is more important than a precise data collection frequency. Timing of data collection should relate to the timing of activities causing the impact. Different phases of an action may produce different impacts that persist after an activity ceases.)

4. Determine monitoring sites or collection areas. (These should be based on the location of the activities causing the impacts, predictions of areas most likely to be affected, and locations where inte- 
TABLE 8.-Explanation of flow chart of monitoring methodology: Phase I. Development of a Monitoring System-Continued

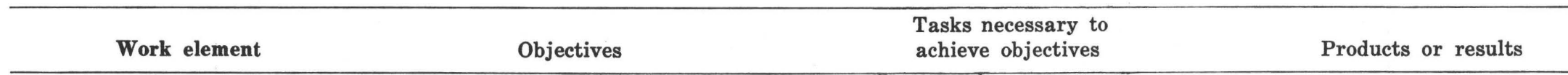

\section{Determine data require-} ments-Continued grated measurements would assist in gaining comprehensive understanding.)

5. Determine method of data collection. (Data can be collected in several ways. For example, vegetative-cover data can be collected by field collection methods or by remote-sensing techniques. Some factors to consider when selecting method of collection are: degree of accuracy, level of detail or scale, agency capability to use method, cost, and how well the method represents resultant impacts.)

6. Determine data type and storage format. (Data format possibilities include statistical tables, charts, graphs, summaries, maps, map overlays, computer printouts, and graphics. Criteria for selecting suitable format include: easy and convenient access to data by all users, intelligibility, interrelatability among formats, and ease of updating.)

7. Determine data analysis method.

1. Review data needs for conformance with monitoring objectives.

2. Revise data needs as necessary to meet monitoring objectives.
Revised list of data requirements. ments in terms of monitoring defined in work element 7 will objectives fulfill monitoring objectives. 
TABLE 8.-Explanation of flow chart of monitoring methodology: Phase I. Development of a Monitoring System-Continued

\begin{tabular}{|c|c|c|c|}
\hline Work element & Objectives & $\begin{array}{l}\text { Tasks necessary to } \\
\text { achieve objectives }\end{array}$ & Products or results \\
\hline $\begin{array}{l}\text { 9. Determine data availa- } \\
\text { bility }\end{array}$ & $\begin{array}{l}\text { To determine extent to } \\
\text { which data needs can be met } \\
\text { under existing agency pro- } \\
\text { grams, and to define data } \\
\text { gaps. }\end{array}$ & $\begin{array}{l}\text { 1. Identify what requirements } \\
\text { are being met under existing pro- } \\
\text { grams, including frequency and } \\
\text { timing of data collection, data col- } \\
\text { lection location, accuracy, and } \\
\text { method of collection. }\end{array}$ & $\begin{array}{l}\text { Table relating data avail- } \\
\text { ability to data requirements } \\
\text { and defining data gaps. }\end{array}$ \\
\hline $\begin{array}{l}\text { 10. Conduct feasibility eval- } \\
\text { uation }\end{array}$ & $\begin{array}{l}\text { To determine if proposed } \\
\text { monitoring system is feasible } \\
\text { within institutional, cost, } \\
\text { funding, personnel, and time } \\
\text { constraints. }\end{array}$ & $\begin{array}{l}\text { 1. Determine cost, personnel, } \\
\text { and time requirements for obtain- } \\
\text { ing data. } \\
\text { 2. Determine agencies' capability } \\
\text { for providing data. } \\
\text { 3. Determine whether proposed } \\
\text { monitoring system is feasible. If } \\
\text { so, work element } 11 \text { has been } \\
\text { achieved. If not, work elements } 1 \\
\text { through } 10 \text { must be repeated at a } \\
\text { reduced level. (There are several } \\
\text { potential approaches for reducing } \\
\text { the monitoring system to a feasible } \\
\text { level: the scope of monitoring ob- } \\
\text { jectives can be reduced; alterna- } \\
\text { tive impact indicators can be } \\
\text { selected; the frequency of data } \\
\text { collection can be reduced; and al- } \\
\text { ternative methods of data collec- } \\
\text { tion can be used.) }\end{array}$ & $\begin{array}{l}\text { Description of cost, per- } \\
\text { sonnel, and time require- } \\
\text { ments for obtaining data. }\end{array}$ \\
\hline
\end{tabular}


TABLE 8.-Explanation of flow chart of monitoring methodology: Phase I. Development of a Monitoring System-Continued

\begin{tabular}{|c|c|c|c|}
\hline Work element & Objectives & $\begin{array}{l}\text { Tasks necessary to } \\
\text { achieve objectives }\end{array}$ & Products or results \\
\hline $\begin{array}{l}\text { 11. Define monitoring sys- } \\
\text { stem. (This is a decision } \\
\text { point. At this point partici- } \\
\text { pating agencies have decided } \\
\text { what objectives the monitor- } \\
\text { ing system will achieve, what } \\
\text { impacts will be monitored, } \\
\text { and what data will be col- } \\
\text { lected. The next phase is im- } \\
\text { plementation and operation of } \\
\text { the monitoring system.) }\end{array}$ & & & \\
\hline
\end{tabular}


[See plate 2 in pocket]

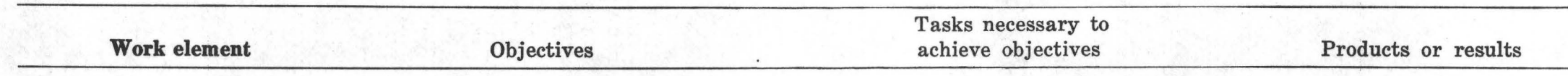

12. Implement monitoring system
To implement the monitoring system.
1. Review suitability of existing institutional entities for operation of monitoring system. (The institutional structure should be interdisciplinary and intergovernmental ; it should include all agencies that have the authority to control impacts. A centralized administrative function should be included in the structure.)

2. Create institutional structure or modify existing institutional structure as needed.

3. Define agency and institutional entity functions and responsibilities. (Functions of individual agencies should include: collecting data pertinent to area of expertise and authority, analyzing data, transmission of data and analyses, funding of data collection, and cooperative funding of administration of monitoring system. A centralized administrative entity should have the following functions: setting data collection and data integration standards, such as base map used for geographic reference; coordination of data flow; data analysis from an interdisciplinary perspective; change assessment; information access to participating agencies; notification of impact levels; assessing critical impact levels and trends; developing and implementing mitigation responses; preparing an annual summary report; soliciting funds for administering monitoring 
TABLE 9.-Explanation of flow chart of monitoring methodology: Phase II. Implementation and Operation of a Monitoring System-Continued

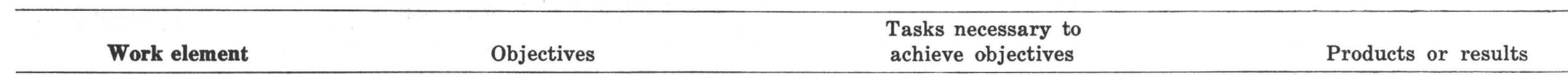

12. Implement monitortoring system-Continued system; and assisting agencies obtain funding for data collection and for carrying out mitigating measures as needed.)

4. Prepare formal written agreement of agency responsibilities; obtain approval.

5. Obtain needed funding.

Formal agreement among participating agencies establishing monitoring system.

Funding arrangement for operation of the monitoring system.

13. Collect data To collect data required for defined monitoring objectives.
To determine the level, location, and duration of activities and impacts.
1. Collect data and submit results.

1. Determine activity and impact levels.

2. Define location of activities and impacts.

3. Determine duration of activities and impacts.

4. Correlate activity and impact data.

\section{Evaluate impacts}

To evaluate the significance of impact levels.
1. Identify impact trends; identify rate of change. (The rate at which an impact is increasing is significant because of the need to respond to impact trends in a timely fashion before critical impact levels are reached.)

2. Identify impacts that have reached critical impact levels. (Critical impact levels requiring immediate notification of participants should be set for each impact being monitored.)

3. Identify impacts that have exceeded legal limits.
Data formatted for integrated storage/ retrieval.

Analytical report of relationship of activities to impacts.

Report(s) describing impact trends, critical level impacts, impacts not in conformance with regulations and standards, and successful mitigating measures. 
TABLE 9.-Explanation of flow chart of monitoring methodology: Phase II. Implementation and Operation of a Monitoring System-Continued

\begin{tabular}{|c|c|c|c|}
\hline Work element & Objectives & $\begin{array}{l}\text { Tasks necessary to } \\
\text { achieve objectives }\end{array}$ & Products or results \\
\hline $\begin{array}{l}\text { 15. Evaluate impacts- } \\
\text { Continued }\end{array}$ & & $\begin{array}{l}\text { 4. Evaluate effectiveness of mitigating } \\
\text { measures. }\end{array}$ & \\
\hline $\begin{array}{l}\text { 16. Response by regula- } \\
\text { tory or responsible agencies }\end{array}$ & $\begin{array}{l}\text { To use agencies' decision- } \\
\text { making, planning, regula- } \\
\text { tion, and enforcement au- } \\
\text { thorities to reduce and pre- } \\
\text { vent impacts. }\end{array}$ & $\begin{array}{l}\text { 1. Plan responses to impact trends. } \\
\text { (Responses to unacceptable impacts can } \\
\text { be directed at the activity causing the im- } \\
\text { pact or at the impact itself. For example, } \\
\text { surface mining causes destruction of wild- } \\
\text { life habitat. Wildlife habitat destruction } \\
\text { can be mitigated by: (1) stopping or re- } \\
\text { ducing the activity, e.g., reducing the area } \\
\text { of land surface disturbance or converting } \\
\text { from surface to underground mining, or } \\
\text { (2) modifying the impact, e.g., developing } \\
\text { wildlife habitat areas to replace destroyed } \\
\text { habitat.) } \\
\text { 2. Respond to critical impact levels: stop } \\
\text { or modify activities causing impact; treat } \\
\text { impact. } \\
\text { 3. Respond to nonconformance with } \\
\text { regulations and standards through en- } \\
\text { forcement and prosecution. Develop addi- } \\
\text { tional regulations, standards, and legal } \\
\text { authority as needed. } \\
\text { 4. Respond to evaluations of mitigating } \\
\text { measures: revise, terminate, or add miti- } \\
\text { gating measures as appropriate. }\end{array}$ & $\begin{array}{l}\text { Plans for responding } \\
\text { to impact trends. } \\
\text { Implementation of ac- } \\
\text { tions that reduce impact } \\
\text { levels. } \\
\text { Enforcement of regu- } \\
\text { lations and standards; } \\
\text { establishment of addi- } \\
\text { tional legal constraints. } \\
\text { Effective mitigating } \\
\text { measures. }\end{array}$ \\
\hline 17. Document changes & $\begin{array}{l}\text { To maintain record of (1) } \\
\text { impact levels that result } \\
\text { from projects and (2) ef- } \\
\text { fectiveness of mitigating } \\
\text { measures in reducing im- } \\
\text { pact levels. }\end{array}$ & 1. Prepare report. & $\begin{array}{l}\text { Annual summary re- } \\
\text { port. }\end{array}$ \\
\hline End products: & $\begin{array}{l}\text { Input to future EIS; re- } \\
\text { duction, control of impacts. }\end{array}$ & & \\
\hline
\end{tabular}




\section{SUMMARY AND CONCLUSIONS}

\section{SUMMARY}

A methodology has been presented for developing, implementing, and operating optimum monitoring systems. The methodology enables monitoring systems to be designed on the basis of activity and impact characteristics, agencies' authority to respond to impacts, monitoring objectives, data availability, and feasibility to operate. The implementation and operation of monitoring systems is based upon functional work agreements among participating agencies, data collection, data analysis, data evaluation, documentation and communication of monitoring results, and agency responses to impact problems.

The Southeast Idaho phosphate EIS was used as a case study for testing the methodology. At a workshop attended by more than 40 agency representatives from Federal, state, and local government participants determined monitoring objectives, selected impacts to be monitored, identified data needs, and reviewed data availability.

\section{CONCLUSIONS}

Monitoring provides information useful for controlling impacts and also provides impact documentation that is useful for predicting the impacts in similar projects. As no one agency has the expertise to monitor all parameters, monitoring should be done as an interagency, intergovernmental effort. Primary users of monitoring data (that is, agencies functioning at a field level) commonly are the most appropriate data collectors and should therefore be actively involved in the development and opera- tion of a monitoring system. In view of the overlapping concerns and responsibilities of many agencies, cooperative data collection (and funding) is appropriate.

Some institutional arrangement (such as an interagency advisory panel, perhaps) should be developed to ensure that monitoring data and analyses are made available to all appropriate agencies in a timely manner without duplication of effort. Such an arrangement would facilitate a comprehensive and integrated picture of how environmental systems are impacted and enable agencies to coordinate their responses to impacts. A report summarizing these activities should be prepared annually.

The ultimate value of a monitoring system is determined by the extent to which it shapes future decisions on Federal actions, and the extent to which agencies effectively respond to impacts.

\section{REFERENCES CITED}

Institute for Environmental Studies, 1976, Documentation of environmental change related to the Columbia electric generating station: Madison, Univ. Wisconsin Institute for Environmental Studies Rept. 62, 135 p.

Office of the Federal Register, 1977, Code of Federal regulations: General Services Administration, title 40 , chap. V, sec. 1500.1 , p. 824 .

Rockefeller Foundation, 1976, The anatomy of an environment: New York, Rockefeller Foundation, Hudson Basin Project final rept., 192 p.

U.S. Geological Survey, 1977, Final Environmental Impact Statement: Development of phosphate resources in Southeastern Idaho, $3 \mathrm{v}$.

U.S. Nuclear Regulatory Commission, Office of Standards Development, 1975, Environmental technical specifications for nuclear power plants: Washington, D.C., U.S. Nuclear Regulatory Comm. Regulatory Guide 4.8, 22 p. 


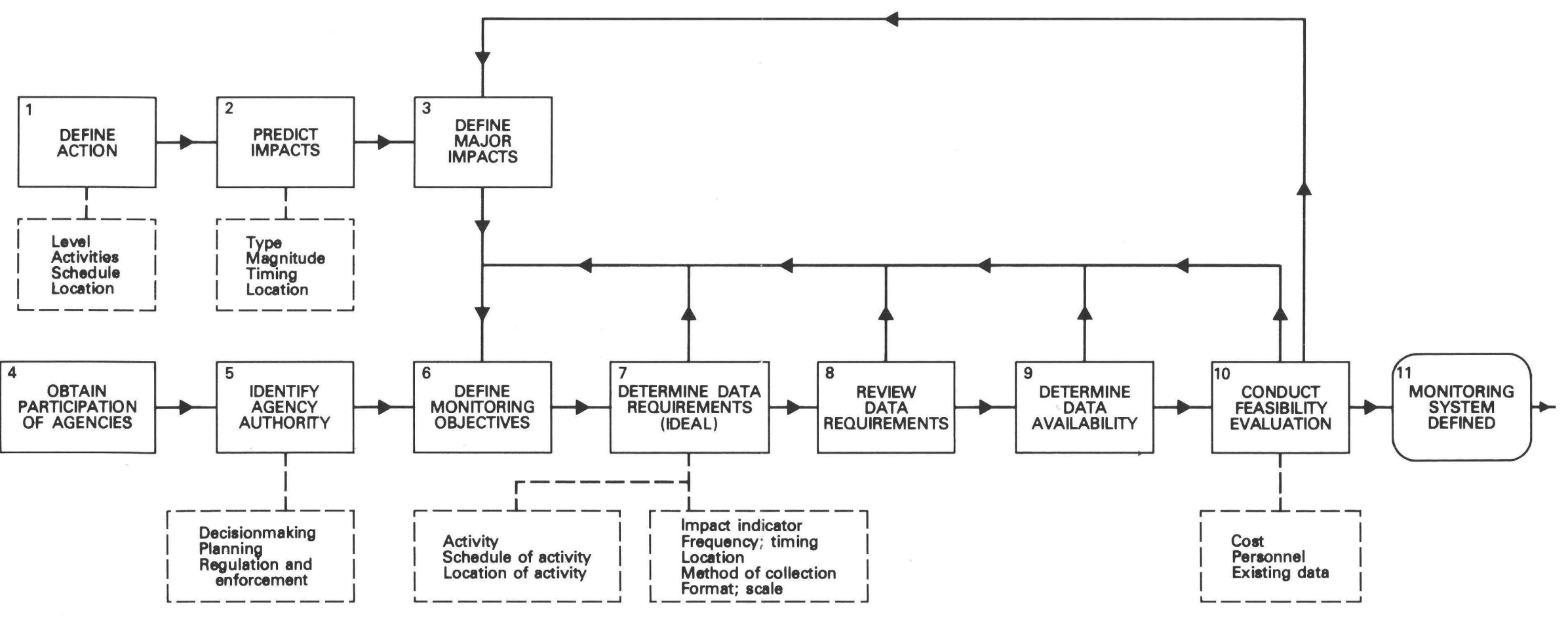

\section{MONITORING METHODOLOGY FLOW CHART: PHASE I. DEVELOPMENT OF A MONITORING SYSTEM}

Flow chart should be used with explanation provided in table 8. The solid numbered boxes correspond to the work elements listed in the table. Dashed boxes are annotations. The rounded box represents a decision point. 


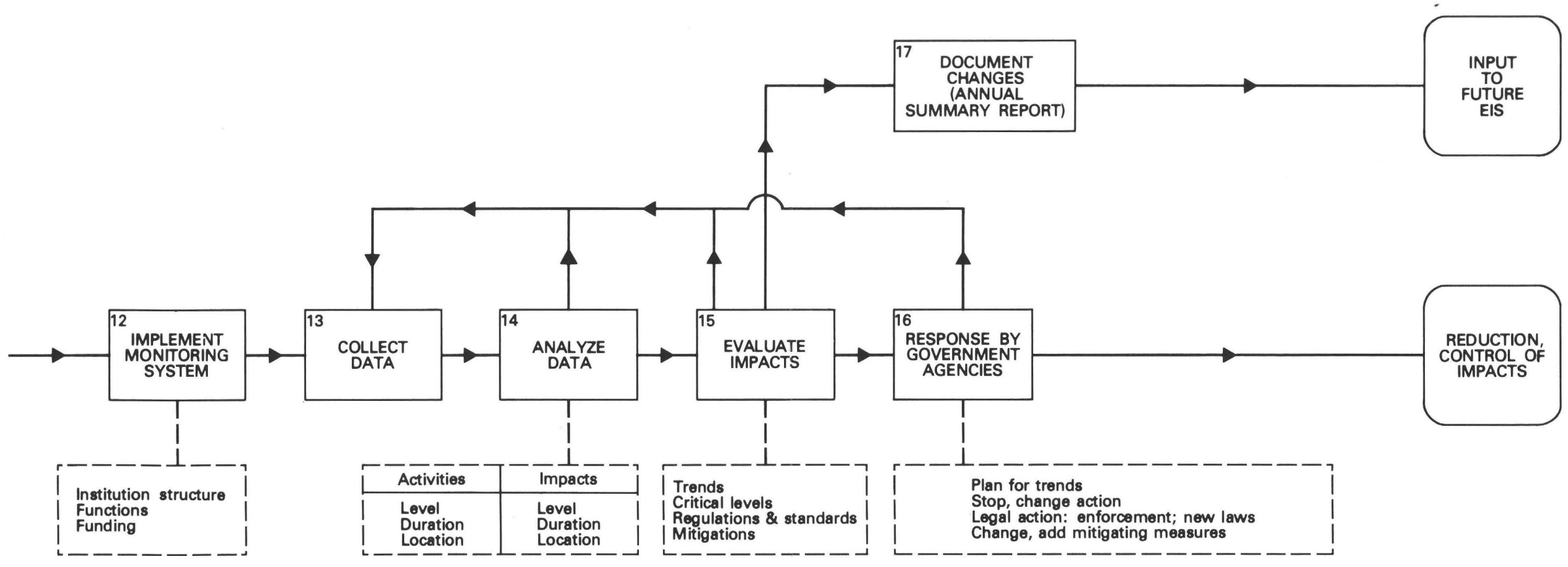

MONITORING METHODOLOGY FLOW CHART:

\section{PHASE II. IMPLEMENTATION AND OPERATION OF A MONITORING SYSTEM}

Flow chart should be used with explanation provided in table 9. The solid numbered boxes correspond to the work elements listed in the table.

Dashed boxes are annotations. The rounded boxes represent end points. 